\title{
RESEARCH
}

Open Access

\section{Efficacy and safety of mesenchymal stem cells co-infusion in allogeneic hematopoietic stem cell transplantation: a systematic review and meta-analysis}

Teng $\mathrm{Li}^{1,2+}$, Chengxin Luo ${ }^{1 \dagger}$, Jiasi Zhang ${ }^{1}$, Ling Wei ${ }^{1}$, Wei Sun ${ }^{3}$, Qin Xie ${ }^{4}$, Yan Liư ${ }^{4}$, Yongli Zhao ${ }^{1}$, Shuangnian $\mathrm{Xu}^{1^{*}}$ and Lihua Wang ${ }^{2^{*}}$

\begin{abstract}
Background: Allogeneic hematopoietic stem cell transplantation (allo-HSCT) is life-saving for severe hematological conditions. However, its outcomes need further improvement, and co-infusion of mesenchymal stem cells (MSCs) may show promise. A growing body of research on this subject exists, while the results of different trials are conflicting. A systematic review and meta-analysis is needed to appraise the real efficacy and safety of MSC cotransplantation in allo-HSCT.

Methods: Studies comparing MSC co-transplantation in allo-HSCT with allo-HSCT alone were searched in six medical databases from inception to June 10, 2020. The primary outcomes were engraftment and graft-versus-host disease (aGVHD and cGVHD, respectively). Other outcomes included overall survival (OS), relapse rate (RR), nonrelapse mortality (NRM), and immune reconstitution. Information was independently extracted by two investigators. Methodological quality was assessed using the Cochrane Collaboration tool. Meta-analysis was performed using RevMan 5.4 .

Results: Six randomized controlled trials (RCTs) and 13 non-randomized controlled trials (nRCTs) were included. MSC co-infusion resulted in shorter times to neutrophil engraftment (RCTs: standardized mean difference (SMD) - 1.20, $p=0.04$; nRCTs: SMD $-0.54, p=0.04$ ) and platelet engraftment (RCTs: SMD $-0.60, p=0.04$; nRCTs: SMD -0.70 , $p=0.01$ ), a lower risk of CGVHD (RCTs: risk ratio (RR) $0.53, p=0.01$; nRCTs: RR 0.50, $p<0.01$ ), and a slightly positive trend towards reducing the risk of aGVHD and NRM, without affecting RR and OS. Subgroup analyses revealed that when MSCs were co-transplanted, children and adolescents, and patients receiving human leukocyte antigen (HLA)nonidentical HSCT showed improvements in engraftment and incidence of GVHD and NRM; adults and patients (Continued on next page)
\end{abstract}

\footnotetext{
* Correspondence: xushuangnian@tmmu.edu.cn; 773569612@qq.com

${ }^{\dagger}$ Teng Li and Chengxin Luo contributed equally to this work.

'Center for Hematology, Southwest Hospital, Army Medical University (Third

Military Medical University), \#30 Gaotanyan Street, Shapingba District,

Chongqing 400038, People's Republic of China

${ }^{2}$ Admin Office of Southwest Hospital, Army Medical University (Third Military

Medical University), \#30 Gaotanyan Street, Shapingba District, Chongqing

400038, People's Republic of China

Full list of author information is available at the end of the article
}

(c) The Author(s). 2021 Open Access This article is licensed under a Creative Commons Attribution 4.0 International License, which permits use, sharing, adaptation, distribution and reproduction in any medium or format, as long as you give appropriate credit to the original author(s) and the source, provide a link to the Creative Commons licence, and indicate if changes were made. The images or other third party material in this article are included in the article's Creative Commons licence, unless indicated otherwise in a credit line to the material. If material is not included in the article's Creative Commons licence and your intended use is not permitted by statutory regulation or exceeds the permitted use, you will need to obtain permission directly from the copyright holder. To view a copy of this licence, visit http://creativecommons.org/licenses/by/4.0/ The Creative Commons Public Domain Dedication waiver (http://creativecommons.org/publicdomain/zero/1.0/) applies to the data made available in this article, unless otherwise stated in a credit line to the data. 
(Continued from previous page)

who received HLA-identical HSCT had lower CGVHD; patients with malignancies exhibited improvements in GVHD and NRM incidence; and patients with non-malignancies experienced accelerated engraftment. Notably, a reduced OS was observed in patients with hematological malignancies undergoing HLA-identical HSCT.

Conclusion: MSC co-infusion generally improved engraftment and reduced cGVHD, without increasing mortality or relapse. Regarding aGVHD and NRM, the effects of MSCs were not quite significant. Specifically, our data support the utilization of MSC co-transplantation in children and young individuals with HLA-nonidentical HSCT, but not in adult patients with hematological malignancies undergoing HLA-identical HSCT.

Keywords: Hematopoietic stem cell transplantation, Mesenchymal stem cells, Engraftment, Graft-versus-host disease

\section{Background}

Throughout the past few decades, allogeneic hematopoietic stem cell transplantation (allo-HSCT) has been a life-saving strategy for many malignant or nonmalignant hematological disorders, providing an opportunity for the complete recovery of blood cellular constituents and graft-versus-leukemia (GVL) effects [1]. Classically, prior to the infusion of hematopoietic stem cells (HSCs), recipients must receive a conditioning regiment (irradiation-based or chemotherapy-based) according to the patient's physical condition, disease type, stage, and donor options, to eliminate malignant hematologic cells and suppress the immune system [1]. Successful engraftment of donor stem cells is the precondition for the therapeutic effect of HSCs. However, several severe complications can restrict the success of transplantation. For example, graft-versus-host disease (GVHD), either in acute or chronic form, is a specific and potentially fatal complication of allo-HSCT [2], as along with disease relapse and opportunistic bacterial, viral, or fungal infections. All of these factors can cause significant morbidity and mortality in allo-HSCT recipients.

Mesenchymal stem cells (MSCs) are a population of multipotent, non-hematopoietic stem cells with the capability to differentiate into various cell types, such as adipocytes, osteocytes, chondrocytes, and cells present in other connective tissues [3, 4]. MSCs, which are present in adult and fetal tissues, could be cultured in vitro and transplanted $[3,5]$. The cells are mainly obtained from bone marrow (BM), adipose tissue, peripheral blood (PB), umbilical cord blood (UCB), and amniotic fluid and amnion $[3,5,6]$. Characterized by plasticity, self-renewal, immunomodulation, and anti-inflammatory properties, MSCs are potentially considered for regeneration medicine, transplantation, and cell therapy for many diseases $[3,5,7]$. Unlike HSCs, MSCs can avoid host immune responses because they do not express human leukocyte antigen (HLA) class-II and many costimulatory molecules, indicating that allogeneic MSCs could be infused without being rejected $[5,8]$. MSCs also modulate immune responses by secreting various mediators and participating in complex interactions with dendritic cells (DCs) and B and $\mathrm{T}$ cells, including $\mathrm{T}$ regulatory cells, natural killer cells (NK cells), and a variety of T helper cells [9]. For example, MSCs act on CD4+ T cells via interferon- $\gamma$ and transforming growth factor- $\beta$ [5]. MSCs suppress monocyte differentiation into DCs and indirectly moderate the eventual specific immune response [8]. In addition, MSCs increase the expression of various hematopoietic factors, providing stromal support for the survival and proliferation of HSCs $[3,5]$. Furthermore, MSCs exert antitumorigenic effects by homing to tumors, inhibiting the vasculature and inducing cell cycle arrest [3]. Therefore, we hypothesized that these characteristics of MSCs would effectively improve the outcomes of allo-HSCT through the induction of mixed chimerism, treatment or prophylaxis of GVHD, acceleration of hematopoietic cell engraftment, and induction of the GVL effect $[2,5]$. Nonetheless, MSCs not only suppress tumor growth but may also promote tumor growth $[3,10]$, and the dual roles of MSCs in tumor cell proliferation and apoptosis remain controversial [11]. Herein, a thorough understanding of the clinical safety and efficacy of MSCs in the treatment of hematological abnormalities and blood malignancies is needed.

Various clinical trials [12-17] have been carried out to investigate the safety and efficacy of MSCs co-infused in allo-HSCT recipients, but controversy persists, probably due to heterogeneous doses and sources of MSCs, diverse patient characteristics, and HSCT types. To date, a few literature reviews $[18,19]$ have summarized these conflicting results but have not yielded any encouraging findings. Focusing on the time point at which MSCs are co-infused during allo-HSCT, we updated the previous work [18] by adding several current original clinical studies and articles that were published in Chinese. Moreover, we performed subgroup analyses based on the aforementioned factors to identify the pros and cons of MSCs co-transplanted with allo-HSCs in a particular clinical situation.

\section{Methods}

This systematic review was performed according to the Preferred Reporting Items for Systematic Reviews and Meta-Analysis (PRISMA) guidelines [20]. Ethical 
approval was not needed, as it was a systematic review of published summary data [21].

\section{Review objective}

The specific research question was the following: Are the outcomes of MSC co-transplantation with allo-HSCs more effective than allo-HSCT alone in people with hematological diseases? The eligibility criteria were defined and listed in Additional file 1.

\section{Data sources and searches}

We (Teng $\mathrm{Li}$ and Shuangnian $\mathrm{Xu}$ ) systematically searched the literature in PubMed, Embase, Web of Science, SinoMed, Cochrane Library, and http:// ClinicalTrials.gov from the date of record to June 10, 2020. The language of publications was restricted to
Chinese and English. The detailed search strategies are presented in Additional file 2.

\section{Study selection}

The titles and abstracts of articles identified using the search strategies were independently screened by 2 reviewers (Teng $\mathrm{Li}$ and Chengxin Luo). Duplicates were eliminated electronically. All potentially relevant publications were retrieved in full, and then the eligibility criteria were applied to the full texts of these studies. Finally, through a discussion or resorting to other team members (Shuangnian $\mathrm{Xu}$ and Lihua Wang), the two reviewers reached a consensus on the papers that should be included. The flow diagram of the literature search and selection process is shown in Fig. 1.

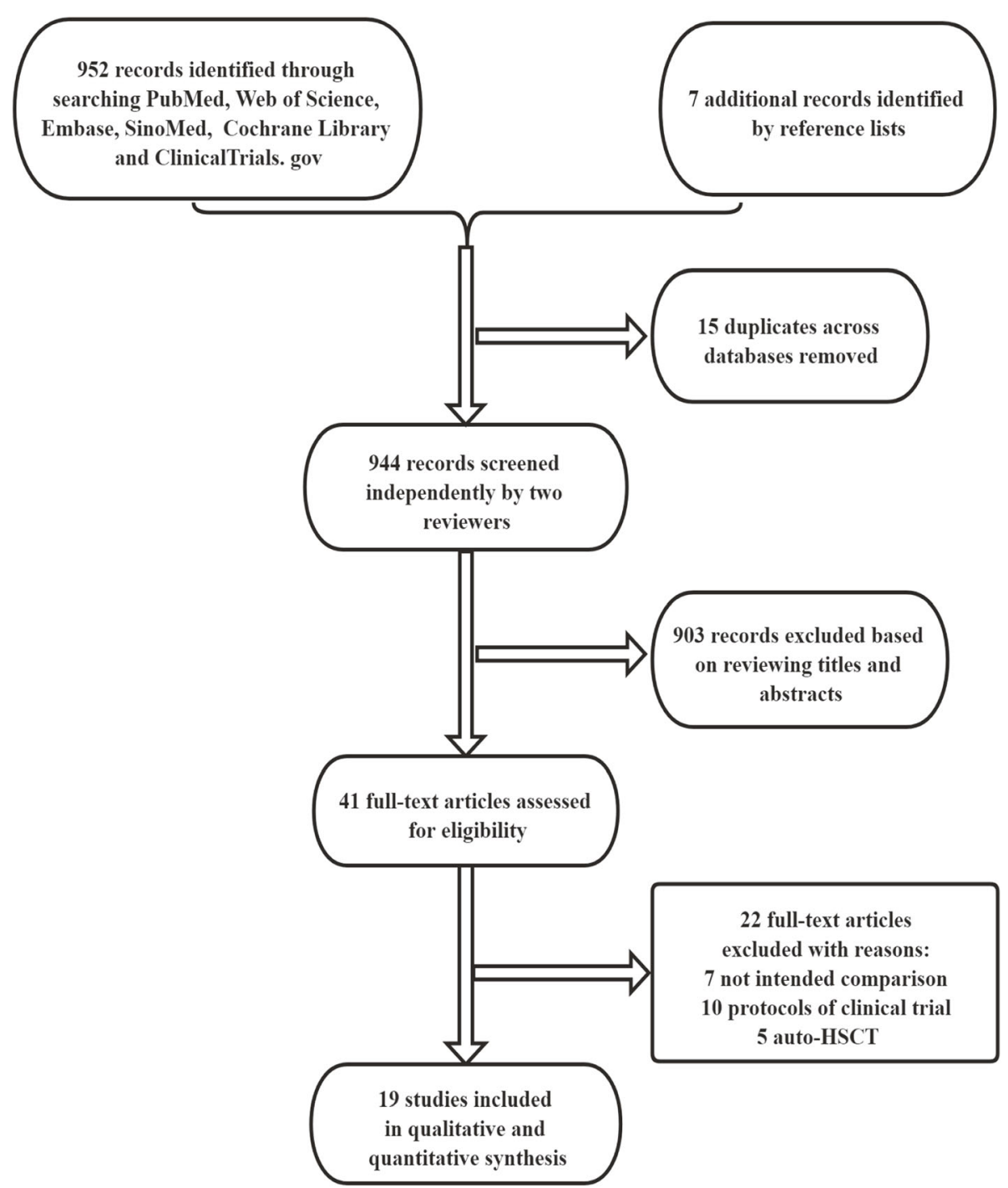

Fig. 1 Flow diagram of study selection 


\section{Definition of outcomes}

We chose engraftment and the incidence of GVHD as primary outcomes and relapse rate (RR), overall survival (OS), treatment-related mortality or non-relapse mortality (TRM/NRM), and immune reconstitution as secondary outcomes. (I) Engraftment: neutrophil engraftment was defined as the time point of the first 3 consecutive days after HSCT when the patient reached an absolute neutrophil count (ANC) of $\geq 0.5 \times 10^{9}$ cells/L [18, 22]; platelet engraftment was defined as the first day that the patient did not have a platelet transfusion and had a platelet count (PLT) of $\geq 20 \times 10^{9}$ cells/L for 7 consecutive days [22]. (II) GVHD: The incidence and severity of GVHD were determined adhering to a National Institutes of Health consensus conference [23]. (III) RR: The relapse rate was defined as the recurrence of disease [18]. (IV) OS: Overall survival was defined as the time from transplantation until death from any cause [18]. (V) TRM/NRM: Death in the absence of persistent relapse was categorized as non-relapse mortality or treatment-related mortality [24]. (VI) Immune reconstitution: The recovery of NK cells, monocytes, DCs, B cells, T cells, and immunoglobulin levels [25, 26].

\section{Data extraction}

Basic study information, patient characteristics, sources of HSCs and MSCs, donor types for HSCs and MSCs, HSC HLA matching, MSC dose, median follow-up time and major clinical outcomes (engraftment, GVHD, RR, OS, NRM/TRM, and immune reconstitution) were independently extracted from each included study by 2 investigators (Teng Li and Chengxin Luo) with specially designed forms. We resolved discrepancies by discussion or resorting to other team members (Shuangnian $\mathrm{Xu}$ and Lihua Wang). The primary characteristics of the included studies are presented in Table 1. All the outcomes extracted from each study are shown in Tables 2, 3, and 4.

\section{Methodological quality assessment}

The methodological quality of the studies was critically assessed in collaboration between the first two authors. For the RCTs, the Cochrane Collaboration tool for assessing the risk of bias ( $\mathrm{RoB})$ in randomized trials was applied [40], and an adapted RoB form adjusted to fit the non-randomized design was used for the nRCTs [18]. Random sequence generation and allocation concealment were appraised for RCTs while comparisons between groups and criteria for selecting participants were evaluated for nRCTs [18]. All studies were appraised for blinding, selective reporting and incomplete outcome data with a three-point scale (low RoB, high RoB, or unclear RoB). Inconsistencies between investigators were resolved by discussion.

\section{Statistical analysis}

This meta-analysis was performed with Review Manager (RevMan) software version 5.4. Considering the apparent heterogeneity, we performed separate meta-analyses for the 6 RCTs and 13 nRCTs. A two-sided $p$ value $\leq 0.05$ was considered statistically significant. For the outcome of engraftment, we chose to report standard mean differences (SMDs). As only median values were documented in most articles, except for studies of Xiang [13] and Xiao et al. [35], we used the range and total number to calculate the mean day of engraftment with the method described by Luo et al. [41]. For OS, the log hazard ratios (HRs) and standard errors were directly extracted from the studies, transformed from the presented $p$ values and events, or indirectly converted from the displayed Kaplan-Meier curves [42]. We merged the log HRs and corresponding 95\% confidence intervals (CIs) of each study using the generic inverse-variance method. Statistical heterogeneity across studies was evaluated using the chi-square-based $Q$ test with a significant level of $p<0.1$ and quantified with $I^{2}$ statistic $\left(I^{2}>50 \%\right.$ indicated high heterogeneity) [43]. If heterogeneity was not significant, a fixed-effect model was adopted for synthesis; otherwise, a random-effect model was employed [21]. Finally, subgroup analyses were conducted based on patients' clinical characteristics, including type of disease, HLA matching, and average age.

\section{Results}

\section{Search results and characteristics of the studies}

As shown in Fig. 1 and Table 1, the titles and abstracts of 959 records were screened. Of these records, 41 publications were selected for full-text review and appraised for eligibility. Seven additional reports were retrieved by checking references cited in these articles. Finally, 19 studies, with 13 published in English and 6 in Chinese, met all preset inclusion criteria for this review [13-16, 22, 24, 27-39]. These studies comprised 16 full publications and 3 meeting abstracts. Ten were conducted in China, 5 in Europe, 1 in the USA, 2 in Iran, and 1 in Korea. Six of the 19 studies were RCTs with 234 participants, and the remaining 13 trials were sorted as nRCTs including 7 prospective controlled studies with 203 patients and 6 historical controlled studies investigating 291 participants. Ten trials assessed adolescents or children, seven examined adults, one trial involved patients aged 3 to 48 years old, and 1 trial did not mention the average age of participants. Two trials were conducted in patients with $\beta$-thalassaemia, one in patients with severe aplastic anemia (SAA), thirteen in patients with hematological malignancies, and the remaining 3 trials in patients with malignant or non-malignant hematonosis together. Six trials administered UCB HSCs; six trials delivered PB HSCs; four trials included patients who 
Table 1 Characteristics of the included studies in systematic review $(N=19)$

\begin{tabular}{|c|c|c|c|c|c|c|c|c|c|}
\hline $\begin{array}{l}\text { First } \\
\text { author, } \\
\text { year, and } \\
\text { country }\end{array}$ & Study & Disease & $\begin{array}{l}\text { No. } \\
\text { (MSCs+/MSCs-) }\end{array}$ & $\begin{array}{l}\text { Median/mean } \\
\text { age (year) } \\
\text { (MSCs+/MSCs-) }\end{array}$ & $\begin{array}{l}\text { HSCs source } \\
\text { (donor type) }\end{array}$ & $\begin{array}{l}\text { HSCs HLA } \\
\text { matching }\end{array}$ & $\begin{array}{l}\text { MSCs source } \\
\text { (donor type) }\end{array}$ & $\begin{array}{l}\text { MSCs dose } \\
\left(10^{6} / \mathrm{kg}\right)\end{array}$ & $\begin{array}{l}\text { Median follow-up } \\
\text { time (month) } \\
\text { (MSCs+/MSCs-) }\end{array}$ \\
\hline $\begin{array}{l}\text { Ning, 2008, } \\
\text { China [24] }\end{array}$ & $\mathrm{RCT}$ & $\mathrm{HM}$ & $25(10 / 15)$ & $38 / 37$ & $\begin{array}{l}\mathrm{BM}, \mathrm{PB} \\
\mathrm{BM}+\mathrm{PB} \text { (RD) }\end{array}$ & ID & $\mathrm{BM}(\mathrm{RD})$ & $0.34(0.03-1.53)$ & $36.6(0.6-44.0)$ \\
\hline $\begin{array}{l}\text { Ghavamzad, } \\
\text { 2010, Iran } \\
\text { [27] }\end{array}$ & $\mathrm{RCT}$ & NMD & $48(25 / 23)$ & $17 / 16$ & $\mathrm{~PB}, \mathrm{BM}(\mathrm{RD})$ & ID & NA (RD) & $1.45-1.80$ & $10(1-28)$ \\
\hline $\begin{array}{l}\text { Liu, 2011, } \\
\text { China [22] }\end{array}$ & $\mathrm{RCT}$ & HM & $55(27 / 28)$ & $30 / 31.5$ & $\mathrm{BM}+\mathrm{PB}(\mathrm{RD})$ & HID & $\mathrm{BM}(\mathrm{RD}, \mathrm{TPD})$ & $0.3-0.5$ & $23.7(0.7-33.5)$ \\
\hline $\begin{array}{l}\text { Wu, 2013b, } \\
\text { China [28] }\end{array}$ & $\mathrm{RCT}$ & $\mathrm{HM}$ & $20(8 / 12)$ & $9.8 / 8.5$ & UCB (URD) & MM & UCB (URD) & $7.19(2.44-10.12)$ & $\begin{array}{l}16.5(11-27) / \\
18.5(12-31)\end{array}$ \\
\hline $\begin{array}{l}\text { Mareika, } \\
\text { 2016, } \\
\text { Belarus [29] }\end{array}$ & $\mathrm{RCT}$ & $\mathrm{HM}$ & $22(10 / 12)$ & $13(5-24)$ & $N A(N A)$ & NA & $\mathrm{BM}(\mathrm{NA})$ & $1.56 \pm 0.4$ & $38(5.7-59.4)$ \\
\hline $\begin{array}{l}\text { Xiang, 2017, } \\
\text { China [13] }\end{array}$ & $\mathrm{RCT}$ & HM & $64(32 / 32)$ & $5.5 \pm 1.4 / 5.2 \pm 1.2$ & PB (URD) & ID & UCB (URD) & 1.0 & 24 \\
\hline $\begin{array}{l}\text { Ball, 2007, } \\
\text { Netherlands } \\
{[16]}\end{array}$ & HCT & $\begin{array}{l}\text { HM and } \\
\text { NMD }\end{array}$ & $61(14 / 47)$ & $\begin{array}{l}8(1-16) / \\
7.1(1-17)\end{array}$ & $\mathrm{PB}(\mathrm{RD})$ & HID & $\mathrm{BM}(\mathrm{RD})$ & $1.6(1.0-3.3)$ & $(3-28) /(32-110)$ \\
\hline $\begin{array}{l}\text { Gonzalo- } \\
\text { Daganzo, } \\
\text { 2009, Spain } \\
{[30]}\end{array}$ & $\mathrm{PCT}$ & $\mathrm{HM}$ & $55(9 / 46)$ & $32 / 35$ & UCB (URD) & MM & BM (URD) & $1.2(1.04-2.22)$ & $\begin{array}{l}7.4(1-22) / \\
24(1-107)\end{array}$ \\
\hline $\begin{array}{l}\text { MacMillan, } \\
\text { 2009, USA } \\
\text { [31] }\end{array}$ & $\mathrm{HCT}$ & $\mathrm{HM}$ & $30(7 / 23)$ & $7.5(0.2-16)$ & UCB (URD) & MM & $\mathrm{BM}(\mathrm{RD})$ & $2.1(0.9-5.0)$ & 81.6 \\
\hline $\begin{array}{l}\text { Baron, 2010, } \\
\text { Belgium [32] }\end{array}$ & $\mathrm{HCT}$ & $\mathrm{HM}$ & $36(20 / 16)$ & $58 / 55$ & PB (URD) & MM & BM (URD) & NA & $18.7(13.3-30.3)$ \\
\hline $\begin{array}{l}\text { Hou, } 2010 \\
\text { China [33] }\end{array}$ & $\mathrm{PCT}$ & $\mathrm{HM}$ & $35(15 / 20)$ & $\begin{array}{l}32(14-45) / \\
28.5(12-48)\end{array}$ & $\mathrm{NA}(\mathrm{RD})$ & HID & $\begin{array}{l}\text { BM (RD, 2; } \\
\text { TPD, 13) }\end{array}$ & $0.41(0.22-0.52)$ & 6 \\
\hline $\begin{array}{l}\text { Bernardo, } \\
2011 \text {, Italy } \\
{[15]}\end{array}$ & $\mathrm{HCT}$ & $\mathrm{HM}$ & $52(13 / 39)$ & $2 / 4$ & UCB (URD) & MM & $\mathrm{BM}(\mathrm{RD})$ & $1.9(1-3.9)$ & $36(28 / 42)$ \\
\hline $\begin{array}{l}\text { Lee, 2013, } \\
\text { Korea [14] }\end{array}$ & $\mathrm{HCT}$ & $\mathrm{HM}$ & $16(7 / 9)$ & $6.9 / 9.5$ & UCB (URD) & MM & UCB (URD) & $\begin{array}{l}1.0 \text { in } 4 \text { pts, } 5.0 \\
\text { in } 3 \text { pts }\end{array}$ & 24 \\
\hline $\begin{array}{l}\text { Wu, 2013a, } \\
\text { China [34] }\end{array}$ & $\mathrm{PCT}$ & $\begin{array}{l}\mathrm{HM} \text { and } \\
\mathrm{NMD}\end{array}$ & $14(5 / 9)$ & $8.8 / 7.8$ & UCB (URD) & MM & UCB (URD) & $5.76(3.12-8.21)$ & $27(24-31)$ \\
\hline $\begin{array}{l}\text { Xiao, 2013, } \\
\text { China [35] }\end{array}$ & $\mathrm{PCT}$ & $\begin{array}{l}\mathrm{HM} \text { and } \\
\mathrm{NMD}\end{array}$ & $15(7 / 8)$ & $\begin{array}{l}30(12-60) / \\
35.5(16-54)\end{array}$ & PB (URD) & NA & UCB (URD) & NA & 15 \\
\hline $\begin{array}{l}\text { Wang, 2015, } \\
\text { China [36] }\end{array}$ & $\mathrm{PCT}$ & NMD & $14(7 / 7)$ & $28(22-43)$ & $\mathrm{PB}(\mathrm{RD})$ & MM & UCB (URD) & Total, 30.0 & $14.5(6-74)$ \\
\hline $\begin{array}{l}\text { Zhang, 2015, } \\
\text { China [37] }\end{array}$ & $\mathrm{HCT}$ & $\mathrm{HM}$ & $49(22 / 27)$ & $\begin{array}{l}22.5(3-48) / \\
23(3-43)\end{array}$ & PB (URD) & MM & UCB (URD) & 1.0 & $22(1-98)$ \\
\hline $\begin{array}{l}\text { Kang, 2017, } \\
\text { China [38] }\end{array}$ & $\mathrm{HCT}$ & $\mathrm{HM}$ & $47(34 / 13)$ & $7(1.5-13)$ & $\mathrm{PB}, \mathrm{BM}(\mathrm{RD})$ & HID & UCB (URD) & 1.0 & $20(0.5-67)$ \\
\hline $\begin{array}{l}\text { Ghavamzad, } \\
\text { 2017, Iran } \\
\text { [39] }\end{array}$ & $\mathrm{PCT}$ & NMD & $70(41 / 29)$ & NA & $\mathrm{NA}(\mathrm{RD})$ & ID & NA (URD) & $1.0-2.0$ & $35.76 / 31.44$ \\
\hline
\end{tabular}

received $\mathrm{UCB}, \mathrm{PB}$, or $\mathrm{BM} \mathrm{HSCs}$; and 3 trials did not report the source of HSCs. Four trials infused HLAidentical HSCs, thirteen trials delivered HLA nonidentical HSCs, and the remaining 2 trials did not mention this parameter. MSCs were extracted from BM in 9 trials and UCB in 8 trials, and two trials did not describe the source of MSCs. In the intervention arms, MSCs were administered at a dose of less than $1 \times 10^{6}$ 
Table 2 Outcomes (engraftment and GVHD) of included studies

\begin{tabular}{|c|c|c|c|c|}
\hline $\begin{array}{l}\text { First author, year, } \\
\text { and country }\end{array}$ & $\begin{array}{l}A N C \geq 0.5 \times 10^{9} / \mathrm{L} \\
\text { (days) }\end{array}$ & $\begin{array}{l}\mathrm{PLT} \geq 20 \times 10^{9} / \mathrm{L} \\
\text { (days) }\end{array}$ & aGVHD (events/total) & $\begin{array}{l}\text { cGVHD } \\
\text { (events/total) }\end{array}$ \\
\hline $\begin{array}{l}\text { Ning, 2008, } \\
\text { China [24] }\end{array}$ & $\begin{array}{l}16.25 \pm 2.602 \text { VS } 15.25 \pm \\
2.602\end{array}$ & $\begin{array}{l}\text { PLT > 50, } 30(16-45) \\
\text { VS } 27(15-64)\end{array}$ & $\begin{array}{l}\text { Grade I-IV, 4/9 VS 11/15; grade II-IV, 1/9 VS 8/15; } \\
\text { grade I-II, 4/9 VS 11/15; grade III-IV, 0/9 VS 0/15 }\end{array}$ & $\begin{array}{l}\text { Lim, 1/7 VS 1/14; } \\
\text { Ext, 0/7 VS 3/14 }\end{array}$ \\
\hline $\begin{array}{l}\text { Ghavamzad, } \\
\text { 2010, Iran [27] }\end{array}$ & 14 VS $13, p=0.16$ & $16 / 15, p=0.34$ & Grade III-IV, 6/25 VS 4/23; $P=0.73$ & NA \\
\hline $\begin{array}{l}\text { Liu, 2011, } \\
\text { China [22] }\end{array}$ & NA & $\begin{array}{l}19.5(8-52) \text { VS } \\
20(10-80)\end{array}$ & $\begin{array}{l}\text { Grade I-IV, 16/27 VS 16/27; grade II-IV, 13/27 VS 9/27; } \\
\text { grade I-II, 16/27 VS 15/27; grade III-IV, 0/27 VS 1/27 }\end{array}$ & $\begin{array}{l}\text { Lim, 9/27 VS } 11 / 24 \\
\text { Ext, } 4 / 27 \text { VS } 4 / 24\end{array}$ \\
\hline $\begin{array}{l}\text { Wu, 2013b, } \\
\text { China [28] }\end{array}$ & $\begin{array}{l}12 \pm 2.31 \text { VS } 25.5 \pm \\
7.94, p=0.003^{*}\end{array}$ & $\begin{array}{l}30(20-45) \text { VS } \\
73(42-135), p=0.004^{*}\end{array}$ & $\begin{array}{l}\text { Grade I-IV, 4/8 VS 8/12; grade II-IV, } 1 / 8 \text { VS 3/12; } \\
\text { grade I-II, 4/8 VS 7/12; grade III-IV, 0/8 VS } 1 / 12\end{array}$ & $\begin{array}{l}\text { Lim, } 1 / 8 \text { VS } 1 / 12 \\
\text { Ext, } 0 / 8 \text { VS } 4 / 12\end{array}$ \\
\hline $\begin{array}{l}\text { Mareika, 2016, } \\
\text { Belarus [29] }\end{array}$ & $\begin{array}{l}19(12-20) \text { VS } 24 \\
(16-45), p=0.09\end{array}$ & $\begin{array}{l}18(10-44) \text { VS } \\
23(16-144), p=0.05\end{array}$ & Grade II-IV, 1/10 VS 3/12; grade III-IV, 0/10 VS 3/12 & Ext, $1 / 10$ VS $4 / 12$ \\
\hline $\begin{array}{l}\text { Xiang, 2017, } \\
\text { China [13] }\end{array}$ & $\begin{array}{l}12.25 \pm 1.59 \text { VS } \\
15.96 \pm 2.20 \\
p=0.000^{*}\end{array}$ & $\begin{array}{l}15.42 \pm 2.59 \text { VS } \\
16.02 \pm 2.86, p=0.382\end{array}$ & NA & $\begin{array}{l}\text { Overall, } 1 / 32 \text { VS } 7 / 32 ; \\
P=0.023\end{array}$ \\
\hline $\begin{array}{l}\text { Ball, 2007, } \\
\text { Netherlands [16] }\end{array}$ & $\begin{array}{l}12(10-17) \text { VS } \\
13(9-28) \\
p=0.15\end{array}$ & $\begin{array}{l}10 \text { (9-18) VS } 13(9-100) \\
p=0.13\end{array}$ & $\begin{array}{l}\text { Grade I-IV, 2/14 VS 14/47; grade I-II, 2/14 VS 12/47; } \\
\text { grade III-IV, 0/14 VS 2/47 }\end{array}$ & $\begin{array}{l}\text { Lim, 1/14 VS 4/47; } \\
\text { Ext, 0/14 VS 2/47 }\end{array}$ \\
\hline $\begin{array}{l}\text { Daganzo, } \\
\text { 2009, Spain [30] }\end{array}$ & $\begin{array}{l}12(10-31) \text { VS } \\
10(9-36), p: \text { NS }\end{array}$ & $\begin{array}{l}44(27-98) \text { VS } \\
32(13-97), p: \text { NS }\end{array}$ & $\begin{array}{l}\text { Grade I-IV, 5/9 VS 29/46; grade II-IV, 4/9 VS 11/46; } \\
\text { grade I-II, 5/9 VS 23/46; grade II-IV, 0/9 VS 6/46 }\end{array}$ & $\begin{array}{l}\text { Lim, } 1 / 8 \text { VS } 8 / 33 \\
\text { Ext, 0/8 VS } 3 / 33\end{array}$ \\
\hline $\begin{array}{l}\text { MacMillan, } \\
\text { 2009, USA [31] }\end{array}$ & $\begin{array}{l}19(8-28) \text { VS } \\
15(11-30), p=0.55\end{array}$ & $\begin{array}{l}\mathrm{PLT}>50,53(36-98) \text { VS } \\
69(31-129) ; p=0.55\end{array}$ & Grade II-IV, 3/8 VS 5/23 & $\begin{array}{l}\text { Overall, } 0 / 8 \text { VS } 4 / 23 \\
p=0.23\end{array}$ \\
\hline $\begin{array}{l}\text { Baron, 2010, } \\
\text { Belgium [32] }\end{array}$ & $\begin{array}{l}\text { ANC }>1,10 \text { VS } 9 ; \\
p=0.2\end{array}$ & $\begin{array}{l}\text { PLT > 100, } 11 \text { VS 13; } \\
p=0.7\end{array}$ & Grade II-IV, 9/20 VS 9/16; $p$ : NS & NA \\
\hline $\begin{array}{l}\text { Hou, 2010, } \\
\text { China [33] }\end{array}$ & $\begin{array}{l}12(11-20) \text { VS } \\
11.5(11-21)\end{array}$ & $\begin{array}{l}19(11-46) \text { VS } \\
19(10-78), p>0.05\end{array}$ & NA & NA \\
\hline $\begin{array}{l}\text { Bernardo, 2011, } \\
\text { Italy [15] }\end{array}$ & $\begin{array}{l}30(17-42) \text { VS } \\
28(13-44)\end{array}$ & $\begin{array}{l}32(14-85) \text { VS } \\
36(18-91), p: \text { NS }\end{array}$ & $\begin{array}{l}\text { Grade I-IV, 5/13 VS 21/39; grade II-IV, 4/13 VS 16/39; } \\
\text { grade I-II, 5/13 VS 11/39; grade III-IV, 0/13 VS 10/39 }\end{array}$ & $\begin{array}{l}\text { Lim, 0/10 VS 1/30; } \\
\text { Ext, 0/10 VS 2/30 }\end{array}$ \\
\hline $\begin{array}{l}\text { Lee, 2013, } \\
\text { Korea [14] }\end{array}$ & $\begin{array}{l}19(16-21) \text { VS } \\
24(17-34), p=0.03^{*}\end{array}$ & $\begin{array}{l}47(33-80) \text { VS } \\
57(41-100), P=0.26\end{array}$ & $\begin{array}{l}\text { Grade I-IV, 5/7 VS 5/8; grade I-II, 4/7 VS 5/8; } \\
\text { grade III-IV, } 1 / 7 \text { VS 0/8 }\end{array}$ & $\begin{array}{l}\text { Ext, } 1 / 7 \text { VS } 3 / 6 \\
P=0.27\end{array}$ \\
\hline $\begin{array}{l}\text { Wu, 2013a, } \\
\text { China [34] }\end{array}$ & $\begin{array}{l}11(7-13) \text { VS } \\
25(19-39), p=0.02^{*}\end{array}$ & $\begin{array}{l}32(22-41) \text { VS } \\
69(55-113), p=0.01^{*}\end{array}$ & $\begin{array}{l}\text { Grade I-IV, 2/5 VS 6/9; grade I-II, 2/5 VS 5/9; } \\
\text { grade III-IV, 0/5 VS } 1 / 9\end{array}$ & $\begin{array}{l}\text { Lim, } 1 / 5 \text { VS } 3 / 9 \\
\text { Ext, } 0 / 5 \text { VS } 1 / 9\end{array}$ \\
\hline $\begin{array}{l}\text { Xiao, 2013, } \\
\text { China [35] }\end{array}$ & $\begin{array}{l}12.143 \pm 2.743 \text { VS } \\
20.5 \pm 7.653\end{array}$ & $\begin{array}{l}8.714 \text { VS } 19.500 \\
p<0.01^{*}\end{array}$ & NA & Overall, 0/7 VS 3/8 \\
\hline $\begin{array}{l}\text { Wang, 2015, } \\
\text { China [36] }\end{array}$ & $\begin{array}{l}17(14-21) \text { VS } \\
21(19-25) \\
p=0.007^{*}\end{array}$ & $\begin{array}{l}19(18-22) \text { VS } \\
21(20-26), p=0.024^{*}\end{array}$ & $\begin{array}{l}\text { Grade I-IV, 2/7 VS 3/7; grade I-II, 2/7 VS 2/7; } \\
\text { grade II-IV, 2/7 VS 3/7; grade III-IV, 0/7 VS } 1 / 7\end{array}$ & $\begin{array}{l}\text { Lim, } 2 / 7 \text { VS } 2 / 7 \\
\text { Ext, } 1 / 7 \text { VS } 3 / 7\end{array}$ \\
\hline $\begin{array}{l}\text { Zhang, 2015, } \\
\text { China [37] }\end{array}$ & $\begin{array}{l}12 \text { (9-22) VS } \\
15(9-26), p=0.041^{*}\end{array}$ & $\begin{array}{l}15(9-38) \text { VS } \\
16(11-46), p=0.78\end{array}$ & Grade I-IV, 11/22 VS 16/27; grade II-IV, 3/22 VS 5/27 & $\begin{array}{l}\text { Lim, } 3 / 20 \text { VS } 5 / 27 \\
\text { Ext, } 1 / 20 \text { VS } 9 / 27\end{array}$ \\
\hline $\begin{array}{l}\text { Kang, 2017, } \\
\text { China [38] }\end{array}$ & 14 VS $15, p=0.691$ & 20 VS $19, p=0.525$ & $\begin{array}{l}\text { Grade I-IV, 15/34 VS 12/13; grade I-II, 9/34 VS 8/13; } \\
\text { grade III-IV, 6/34 VS 4/13 }\end{array}$ & $\begin{array}{l}\text { Lim, 5/34 VS 2/13; } \\
\text { Ext, 4/34 VS 2/13 }\end{array}$ \\
\hline $\begin{array}{l}\text { Ghavamzad, } \\
\text { 2017, Iran [39] }\end{array}$ & NA & $\begin{array}{l}27.2(22-31) \text { VS } \\
36.6(22-50), p=0.26\end{array}$ & Overall, 23/41 VS 19/29 & $\begin{array}{l}\text { Overall, } 9 / 41 \text { VS } \\
11 / 29\end{array}$ \\
\hline
\end{tabular}

MSCs+ VS MSCs-

Lim limited, Ext extensive, NA not available, NS not significant

*Statistically significant

cells $/ \mathrm{kg}$ in 4 trials, between $1 \times 10^{6}$ and $5 \times 10^{6}$ cells $/ \mathrm{kg}$ in 11 trials, and more than $5 \times 10^{6}$ cells $/ \mathrm{kg}$ in 2 trials, and the other 2 trials did not provide information about the dose. The median durations of follow-up were within 1 year in 2 trials, between 1 and 2 years in 7 trials, between 2 and 3 years in 4 trials, and 3 years or more in 4 trials. In the remaining two trials, the durations of follow-up varied substantially between groups, namely, 3 to 28 and $7.4(1-22)$ months in the MSC groups and 32 to 110 and 24 (1-107) months in the control groups, respectively.

All patients received intensive conditioning regimens, GVHD prophylaxis, and supportive care. Patients in the control groups underwent HSCT alone. Patients in the experimental groups received a co-infusion of MSCs with allogeneic HSCs, both of which were administrated within day "0" whenever allowed by the patient's condition, otherwise within the next $24 \mathrm{~h}$. The main outcomes 
Table 3 Outcomes (OS, TRM/NRM, RR) of included studies

\begin{tabular}{|c|c|c|c|c|c|}
\hline \multicolumn{6}{|c|}{ Survival rates with a varied follow-up time } \\
\hline \multirow[t]{2}{*}{ Author, year } & \multicolumn{2}{|c|}{ Intervention group, $\mathrm{HSCT}+\mathrm{MSC}$} & \multicolumn{2}{|l|}{ Control group, $\mathrm{HSCT}$} & \multirow[t]{2}{*}{$P$ value } \\
\hline & Follow-up, months & Survival & Follow-up, months & Survival & \\
\hline \multirow[t]{2}{*}{ Ball, 2007 [16] } & \multirow[t]{2}{*}{ Range 3-28 } & OS $72 \%$ & \multirow[t]{2}{*}{ Range $32-110$} & OS 63\% & Not reported \\
\hline & & RR $18 \%$ & & RR 26\% & Not reported \\
\hline \multirow[t]{4}{*}{ Daganzo, 2009 [30] } & \multirow[t]{4}{*}{ Median 7.4 , range $1-22$} & OS $89 \%$ & \multirow[t]{4}{*}{ Median 24, range 1-107 } & OS $53 \%$ & $=0.19$ \\
\hline & & RR $11 \%$ at 22 months & & RR $13 \%$ at 60 months & Not reported \\
\hline & & DFS $71 \%$ & & DFS $45 \%$ & Not reported \\
\hline & & TRM 11\% (95\% Cl 2-71) & & TRM 37\% (95\% Cl 25-54) & Not reported \\
\hline \multirow[t]{3}{*}{ Wu, 2013b [28] } & \multirow[t]{3}{*}{ Median 16.5 , range $11-27$} & OS $75 \%$ & \multirow[t]{3}{*}{ Median 18.5 , range $12-31$} & OS $67 \%$ & $>0.05$ \\
\hline & & RR $25 \%$ & & RR $16.67 \%$ & Not reported \\
\hline & & TRM 25\% & & TRM 33\% & $>0.05$ \\
\hline \multirow[t]{2}{*}{ Wu, 2013a [34] } & \multirow[t]{2}{*}{ Median 27, range 24-31 } & OS $80 \%$ & \multirow[t]{2}{*}{ Not reported } & OS $56 \%$ & $=0.58$ \\
\hline & & TRM 0\% & & TRM $22.2 \%$ & $=0.51$ \\
\hline \multicolumn{6}{|c|}{ Survival measured at fixed measure points } \\
\hline \multirow[t]{2}{*}{ Author, year } & \multicolumn{2}{|c|}{ Intervention group, $\mathrm{HSCT}+\mathrm{MSCS}$} & \multicolumn{2}{|l|}{ Control group, $\mathrm{HSCT}$} & $P$ value \\
\hline & Measure time point, years & Survival & Measure time point, years & Survival & \\
\hline \multirow[t]{4}{*}{ Baron, 2010 [32] } & \multirow[t]{4}{*}{1} & OS $60 \%$ & \multirow[t]{4}{*}{1} & OS $38 \%$ & $=0.1$ \\
\hline & & DFS 5\% & & DFS 0\% & $>0.05$ \\
\hline & & TRM 10\% & & TRM 37\% & $=0.02^{*}$ \\
\hline & & RR 30\% & & RR 25\% & $=0.9$ \\
\hline Zhang, 2015 [37] & 1 & OS $72.7 \%$ & 1 & OS $85.2 \%$ & $=0.472$ \\
\hline & & RR 9.1\% & & RR $22.2 \%$ & $=0.396$ \\
\hline & & CRR 9.1\% & & CRR $33.3 \%$ & $=0.093^{*}$ \\
\hline Xiang, 2017 [13] & 1 & OS $87 \%$ & 1 & OS $75 \%$ & $=0.202$ \\
\hline & & CRR 16\% & & CRR $25 \%$ & $=0.351$ \\
\hline Lee, 2013 [14] & 2 & OS $85.7 \%$ & 2 & OS $55.6 \%$ & $=0.15$ \\
\hline Liu, 2011 [22] & 2 & OS $69.7 \%$ & 2 & OS $64.3 \%$ & $=0.737$ \\
\hline & & RR 12.8\% & & RR 9.3\% & $=0.721$ \\
\hline MacMillan, 2009 [31] & 3 & OS 75\% (95\% Cl 45-100) & 3 & OS 46\% (95\% Cl 26-66) & $=0.38$ \\
\hline Ning, 2008 [24] & 3 & OS $40 \%$ & 3 & OS $66.7 \%$ & Not reported \\
\hline & & DFS 30\% & & DFS $66.7 \%$ & $=0.035^{*}$ \\
\hline & & RR $60.0 \%$ & & RR 20\% & $=0.020^{*}$ \\
\hline Bernardo, 2011 [15] & 3 & OS 63\% (95\% Cl 43-97) & 3 & OS 64\% (95\% Cl 48-79) & NS \\
\hline & & DFS 67\% (95\% Cl 41-94) & & DFS 56\% (95\% Cl 40-72) & NS \\
\hline & & TRM 8\% (95\% Cl 1-51) & & TRM 21\% (95\% Cl 11-38) & NS \\
\hline & & RR 25\% (95\% Cl 9-67) & & RR 23\% (95\% Cl 13-42) & NS \\
\hline Kang, 2017 [38] & 3 & OS $70.6 \%$ & 3 & OS 23.1 & $=0.004^{*}$ \\
\hline & & DFS 52.9\% & & DFS 0\% & $=0^{*}$ \\
\hline & & TRM $11.8 \%$ & & TRM $46.2 \%$ & $=0.017^{*}$ \\
\hline & & RR $32.4 \%$ & & RR 53.8\% & $=0.199$ \\
\hline Ghavamzadeh, 2017 [39] & 3 & OS $70 \%$ & 3 & OS 61\% & $=0.78$ \\
\hline & & DFS 54\% & & DFS 61\% & $=0.35$ \\
\hline Mareika, 2016 [29] & $>3$ & OS $(90 \pm 9.5) \%$ & $>3$ & OS $(83 \pm 10.7) \%$ & Not reported \\
\hline & & RR $10 \%$ & & RR 0\% & Not reported \\
\hline
\end{tabular}

OS overall survival, TRM/NRM treatment-related mortality/non-relapse mortality, $R R$ relapse rate, DFS disease free survival, CRR cumulative relapse rate, NS not significant

*Statistically significant 
Table 4 Outcomes (immune reconstitution) of included studies

\begin{tabular}{|c|c|c|c|c|c|}
\hline Study & Outcome & HSCT+MSCs group & HSCT group & Time points & $p$ value \\
\hline \multirow[t]{3}{*}{ Ball et al. [16] } & NK cells $\left(\times 10^{9} / L\right)$ & $0.497,95 \%$ Cl $0.347-0.646$ & $0.252,95 \% \mathrm{Cl} 0.173-0.33$ & 28 days & $=0.02^{*}$ \\
\hline & WBC $>1 \times 10^{9} / L$ (days) & $11.5,95 \%$ Cl 9.0-14.8 & $14.9,95 \% \mathrm{Cl} 10.1-26.0$ & NA & $=0.009^{*}$ \\
\hline & NK and T cells & NA & NA & 3 months & NS \\
\hline Liu et al. [22] & WBC (days) & $12(10-21)$ & $12(10-23)$ & NA & NS \\
\hline Ghavamzadeh et al. [33] & WBC $>0.5 \times 10^{9} / L$ (days) & $17.7(15-20)$ & $17.7(15-20)$ & NA & $=0.83$ \\
\hline \multirow[t]{2}{*}{ Mareika et al. [29] } & $(\mathrm{NK})$ cells $\left(\times 10^{9} / \mathrm{L}\right)$ & $0.1(0.02-0.23)$ & $0.01(0.002-0.06)$ & 100 days & $=0.07$ \\
\hline & B cells $\left(\times 10^{9} / L\right)$ & $0.18(0.11-0.43)$ & $0.07(0.02-0.19)$ & 100 days & $=0.05^{*}$ \\
\hline Lee et al. [14] & Lymphocyte subpopulations & NA & NA & $28,100,180$ and 365 days & NS \\
\hline $\begin{array}{l}\text { Gonzalo-Daganzo } \\
\text { et al. [30] }\end{array}$ & Lymphocyte subpopulations & NA & NA & NA & NS \\
\hline Baron et al. [32] & T cells $\left(\times 10^{9} / \mathrm{L}\right)$ & $0.29(0.004-0.54)$ & $0.202(0.041-0.886)$ & 28 days & NS \\
\hline Wu et al. [34] & $\begin{array}{l}\text { Absolute lymphocyte count } \\
\left(\times 10^{9} / \mathrm{L}\right)\end{array}$ & $0.305(0.196-0.445)$ & $0.256(0.150-0.368)$ & 30 days & $=0.35$ \\
\hline \multirow[t]{2}{*}{ Xiang [13] } & \multicolumn{3}{|c|}{ The levels of serum immunoglobulins $\lg A, \lg G$, IgM, and $\lg E$} & 1,3 , and 6 months & $<0.05^{*}$ \\
\hline & \multicolumn{3}{|c|}{ The levels of T lymphocytes and B cells } & & \\
\hline
\end{tabular}

NA not available, NS not significant

*Statistically significant

were engraftment of platelets and neutrophils, and acute and chronic GVHD. The secondary outcomes included the relapse rate, overall survival, non-relapse mortality or treatment-related mortality, and immune reconstitution.

\section{Risk of bias analysis}

Figure 2 shows the results of the quality assessment for each study. No trial included more than 100 participants and 5 trials recruited fewer than 20 patients [14, 28, 3436]. Most studies among the 6 RCTs had a low risk of bias, but the 13 nRCTs had a higher risk of bias according to the predefined methodological quality assessment tool.

\section{Engraftment}

Four RCTs and $10 \mathrm{nRCTs}$ provided sufficient information on the neutrophil engraftment that ranged from 10.5 to 29.82 mean days in the experimental group and from 12.31 to 28.1 mean days in the control group. We estimated the means and standard deviations (SD) from the given sample sizes, medians, and ranges [41]. The studies of Ghavamzadeh et al. [27] and Kang et al. [38] were not included in the meta-analysis of these results, as they only supplied the median values. Data from the study of Baron et al. [32] were excluded because a neutrophil count of $\geq 1.0 \times 10^{9}$ cells/L was defined as the standard of neutrophil engraftment. The results from the studies of Liu et al. [22] and Ghavamzadeh et al. [39] were not included because they monitored white blood cell engraftment instead of neutrophil engraftment. Both meta-analysis of RCTs with 130 participants and nRCTs with 341 participants indicated that patients who received MSC co-infusion needed a shorter time to reach neutrophil recovery than the control group (4 RCTs: SMD $-1.20,95 \%$ CI -2.32 to $-0.08, p=0.04, I^{2}=86 \%$; 10 nRCTs: SMD $-0.54,95 \%$ CI -1.05 to $-0.03, p=$ $0.04, I^{2}=74 \%$; Fig. 3a, b).

Regarding platelet engraftment, we did not include the studies of Ghavamzadeh et al. [27] and Kang et al. [38] due to a lack of usable information; data from the studies of Ning et al., Baron et al., and MacMillan et al. [24, $31,32]$ were not included because they defined platelet counts of $\geq 100 \times 10^{9}$ cells/L or $\geq 50 \times 10^{9}$ cells/L as the standard of platelet recovery. As a result, only 4 RCTs and $10 \mathrm{nRCTs}$ were selected for synthesis, and the mean engraftment time ranged from 8.71 to 52.05 days for the MSC co-infused groups and from 16.02 to 78.94 days for the control groups. Both RCTs with 157 participants and nRCTs with 381 participants revealed that the patients from the MSC co-infusion group experienced a faster recovery of platelets than patients from the HSCT alone group (4 RCTs: SMD - 0.60, 95\% CI -1.17 to $0.02, p=0.04, I^{2}=63 \% ; 10$ nRCTs: SMD $-0.70,95 \% \mathrm{CI}$ -1.24 to $-0.16, p=0.01, I^{2}=79 \%$; Fig. 3c, d).

According to the funnel plots present in Additional file 3, publication bias was obvious for the outcomes of neutrophil and platelet engraftment. Meanwhile, statistical heterogeneity existed, as indicated by the $\mathrm{Tau}^{2}, \mathrm{Chi}^{2}$, and $I^{2}$ tests (Fig. 3a-d). Thus, a random-effect model was adopted. Sensitivity was also assessed using leave-one-out analyses to estimate the relative contribution of each single study to the overall heterogeneity. When the study of Wu et al. [28] was 


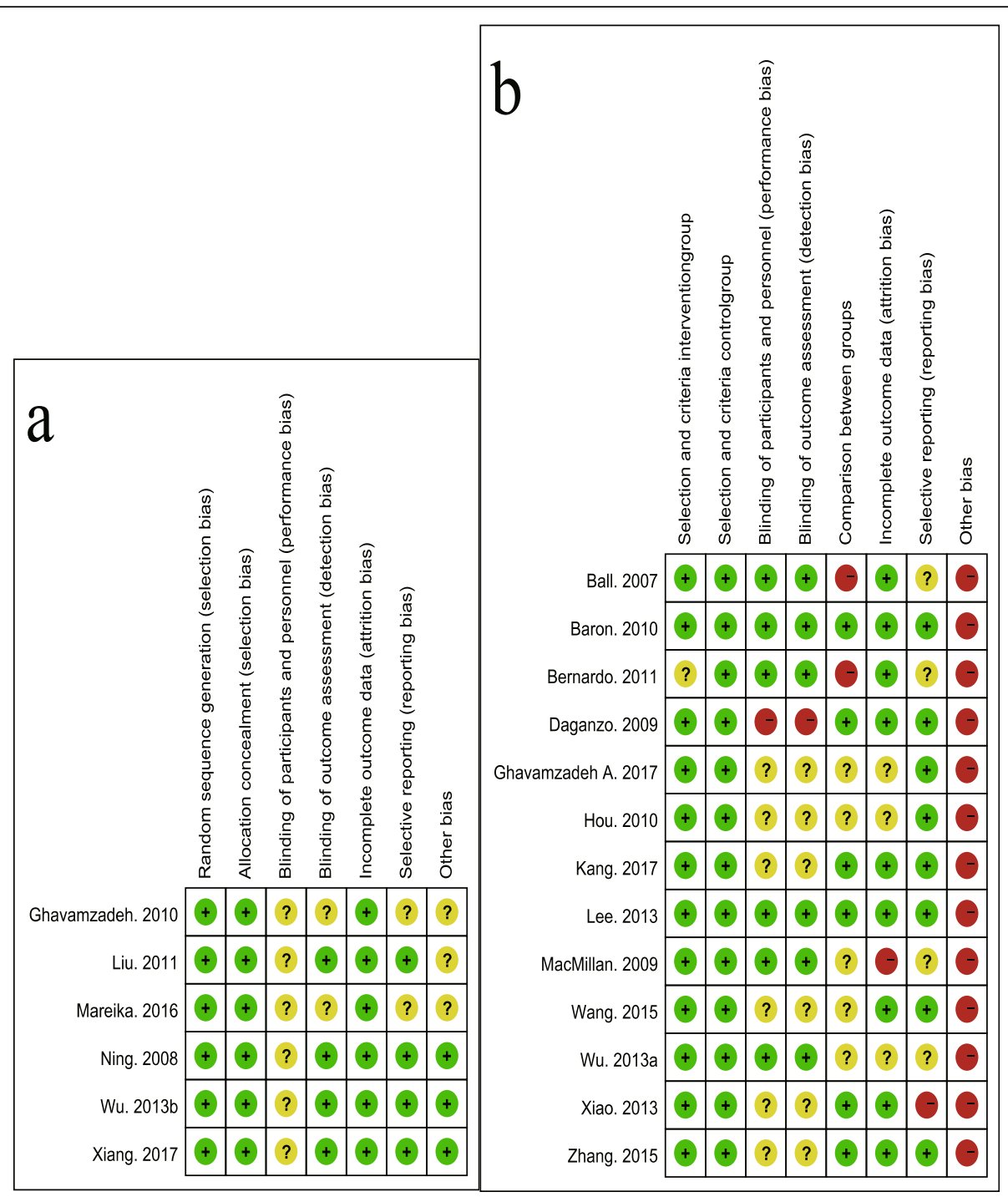

Fig. 2 Risk of Bias (RoB) judgment. RoB assessments for the included a) six RCTs and $\mathbf{b}$ thirteen nRCTs. Green sign means low RoB, yellow sign means unclear RoB, red sign means high RoB

abandoned, the score of $I^{2}$ decreased sharply from 63 to $0 \%$ in the meta-analysis of PLT engraftment in RCTs, which may be because it was the only trail that used MSCs in excess of $5 \times 10^{6}$ cells per kilogram; no significant changes in $I^{2}$ values were observed in the other 3 meta-analyses.

In addition, we conducted subset analyses (details are shown in Additional file 4) according to the dose of MSCs, and all the studies were sorted into three groups. The study of Xiao et al. [35] was excluded because it failed to document the dosage of MSCs. These analyses showed that with the increasing of MSC dose, hematopoietic recovery was more effective, although the results of subsets of nRCTs with MSC doses ranging from $1 \times 10^{6}$ to $5 \times 10^{6}$ cells per kilogram were not obvious, which may be partially attributed to the potential confounders of the study design. However, as the number of included studies and sample size in some subgroups were limited, all these results should be interpreted with caution.

GVHD

The incidence of grade I-IV aGVHD was reported in 3 RCTs [22, 24, 28]. The study of Ghavamzadeh et al. [27] only provided the data on grade III-IV aGVHD; Mareika et al. [29] covered the occurrences of grade II-IV and grade III-IV aGVHD; the study of Xiang [13] was not included, as it did not report this outcome. Among the 13 nRCTs, nine studies reported the incidence of overall aGVHD; two [31, 32] provided only the data for grade 


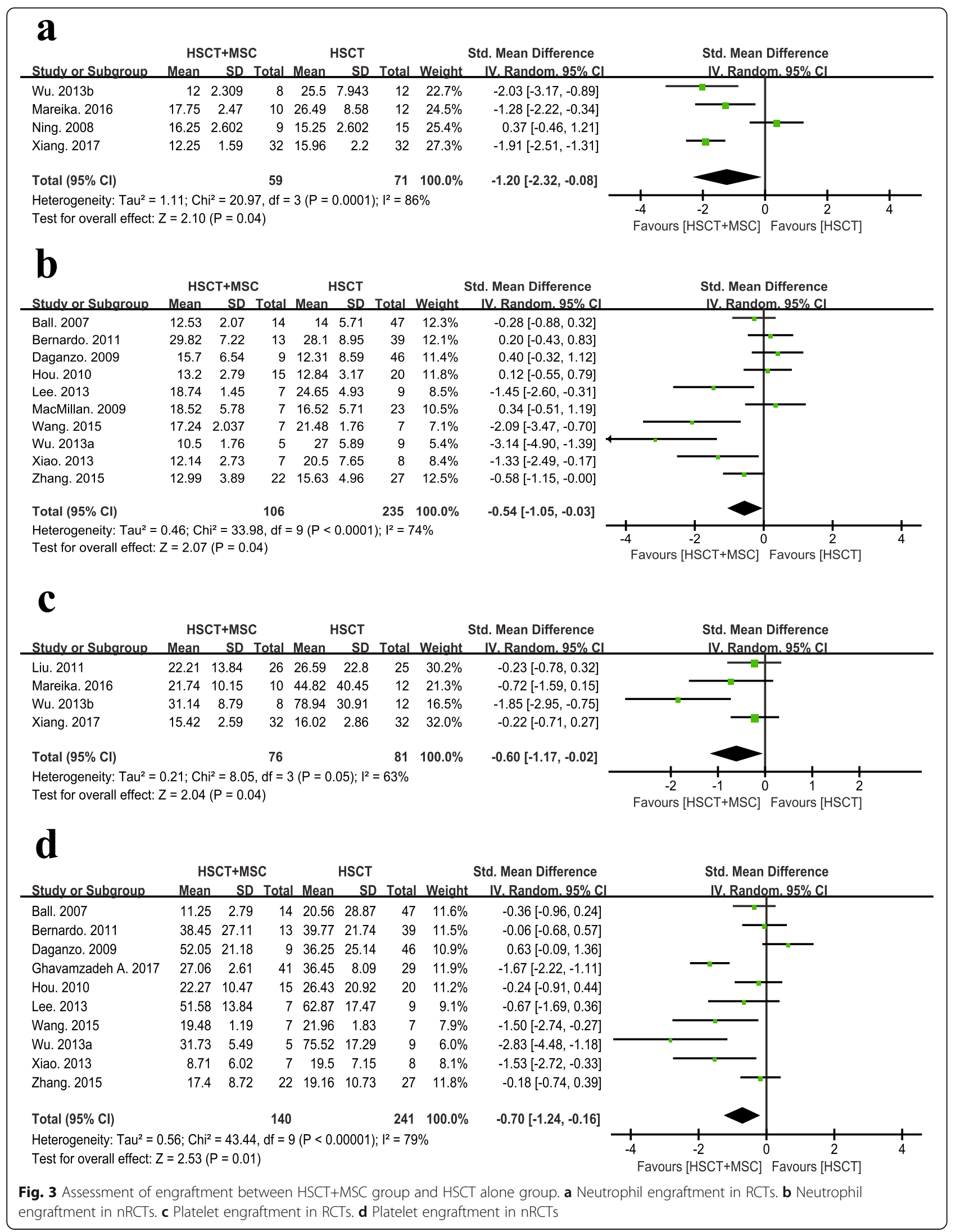


II-IV aGVHD; and the remaining 2 studies [33, 35] did not mention this outcome. Regarding the incidence of grade I-IV aGVHD, no statistically significant differences were observed in the meta-analysis including 3 RCTs with 98 cases (RR $0.84,95 \%$ CI 0.59 to $1.19, p=0.33$, $I^{2}=0 \%$; Fig. 4a). In the meta-analysis including $9 \mathrm{nRCTs}$ with 377 participants, patients treated with a MSC coinfusion had a significantly lower rate of grade I-IV aGVHD incidence than the control group (RR 0.74, 95\% CI 0.60 to $0.91, p=0.005, I^{2}=0 \%$; Fig. $4 \mathrm{~b}$ ). No difference was observed between groups in outcomes of grade IIIV, grade III-IV, and grade I-II aGVHD from either the meta-analysis of RCTs or with the meta-analysis of nRCTs (Fig 4a, b).

Among the 19 candidate studies, three [27, 32, 33] did not provide information about cGVHD incidence, and two $[14,29]$ presented only the incidence of extensive cGVHD without data on the number of people who developed limited cGVHD. As a result, 4 RCTs with 156 participants (RR $0.53,95 \%$ CI 0.33 to $0.87, p=0.01, I^{2}=$ 25\%; Fig. 5a) and $10 \mathrm{nRCTs}$ with 380 participants (RR $0.50,95 \%$ CI 0.33 to $0.75, p=0.001, I^{2}=0 \%$; Fig. $5 \mathrm{~b}$ ) were separately included in meta-analysis for the overall occurrence of cGVHD, and the results of both analyses of RCTs and nRCTs suggested that the MSC co-infusion significantly reduced the overall incidence of cGVHD. Specifically, regarding the outcome of limited cGVHD, no statistically significant difference was found between groups. However, patients in the MSC group had a lower risk of extensive cGVHD than patients in the control groups, as evidenced by the results of the metaanalysis with $8 \mathrm{nRCTs}$ (RR $0.37,95 \% \mathrm{CI} 0.17,0.81, I^{2}=$ $0 \%, p=0.01$; Fig. $5 \mathrm{~b}$ ); moreover, a slight trend was observed in the meta-analysis of 4 RCTs (RR $0.44,95 \% \mathrm{CI}$ $0.17,1.09, I^{2}=0 \%, p=0.08$; Fig. 5a).

Both funnel plots for aGVHD and cGVHD (Additional file 5) showed asymmetry, indicating the existence of publication bias. The heterogeneity was not statistically significant, as indicated by the $\mathrm{Tau}^{2}, \mathrm{Chi}^{2}$, and $I^{2}$ tests.

\section{Overall survival}

Fourteen trials estimated the effect of the MSC coinfusion on the overall survival of HSCT recipients, of which four studies [14-16, 39] were excluded because they failed to provide sufficient information that could be transformed into $\operatorname{logHR}$ and SE values. The outcomes of the meta-analyses of the remaining 4RCTs (164 participants) and 6 nRCTs (231 participants) (HR 1.54, 95\% CI 0.81 to $2.93, p=0.18, I^{2}=$ $0 \%$, Fig. 6a; HR 0.60, 95\% CI 0.35 to $1.02, p=0.06$, $I^{2}=34 \%$, Fig. 6b; respectively) did not suggest a statistically significant difference in OS between the groups. Publication bias was not obviously visualized from the funnel plot of OS, which is shown in Additional file 6a. Heterogeneity was not statistically significant, as indicated by the $\mathrm{Tau}^{2}, \mathrm{Chi}^{2}$, and $I^{2}$ tests.

\section{Relapse rate}

Eleven studies reported the occurrence of relapse in both the MSC group and the control group, but studies of Ball et al. [16] and Gonzalo-Daganzo et al. [30] were excluded because of varying follow-up times between groups. Both the meta-analyses of 5 RCTs with 186 participants and 4 nRCTs with 184 participants (RR 1.34, 95\% CI 0.74 to $2.43, p=0.34, I^{2}=13 \%$, Fig. 6c; RR 0.74, $95 \%$ CI 0.45 to $1.22, p=0.24, I^{2}=0 \%$, Fig. $6 \mathrm{~d}$; respectively) suggested no difference between patients who did or did not receive MSC co-transplantation. Apparent publication bias was observed from the funnel plot of RR (Additional file 6b), and heterogeneity was not statistically significant, as indicated by the $\mathrm{Tau}^{2}, \mathrm{Chi}^{2}$, and $I^{2}$ tests.

\section{TRM/NRM}

For the TRM/NRM, the results of meta-analyses varied between the 3 RCTs with 100 participants and the 3 nRCTs with 97 participants (OR 0.59, 95\% CI 0.20 to $1.73, p=0.34, I^{2}=0 \%$, Fig. 6e; OR $0.18,95 \%$ CI 0.06 to 0.54, $p=0.002, I^{2}=0 \%$, Fig. 6f; respectively). However, none of the odds ratios (ORs) was greater than 1, and no statistically significant heterogeneity was observed. We concluded that a slight trend existed in which patients infused with MSCs may have a lower risk of TRM/ NRM. The funnel plot was not applicable due to the small number of studies. The heterogeneity was not statistically significant, as indicated by the $\mathrm{Tau}^{2}, \mathrm{Chi}^{2}$, and $I^{2}$ tests.

\section{Immune reconstitution}

Multiple studies have investigated the effect of MSC cotransplantation in allo-HSCT on immune reconstitution. However, all these data from each trial were difficult to combine because of the use of various parameters and time points, and we only provide a qualitative description. In the study of Ball et al., the recovery time of NK cells at 28 days post transplantation was faster in recipients who received the MSC co-infusion than in the controls [16]. The study of Xiang [13] showed that the levels of lymphocyte subpopulations and immunoglobulins in patients treated with MSCs were significantly higher than those in the control group at the 1st, 3rd, and 6th months after transplantation. The other seven trials $[14,22,29,30,32,34,39]$ did not observe differences in the lymphocyte recovery time after transplantation between the two groups (details are shown in Table 4). 


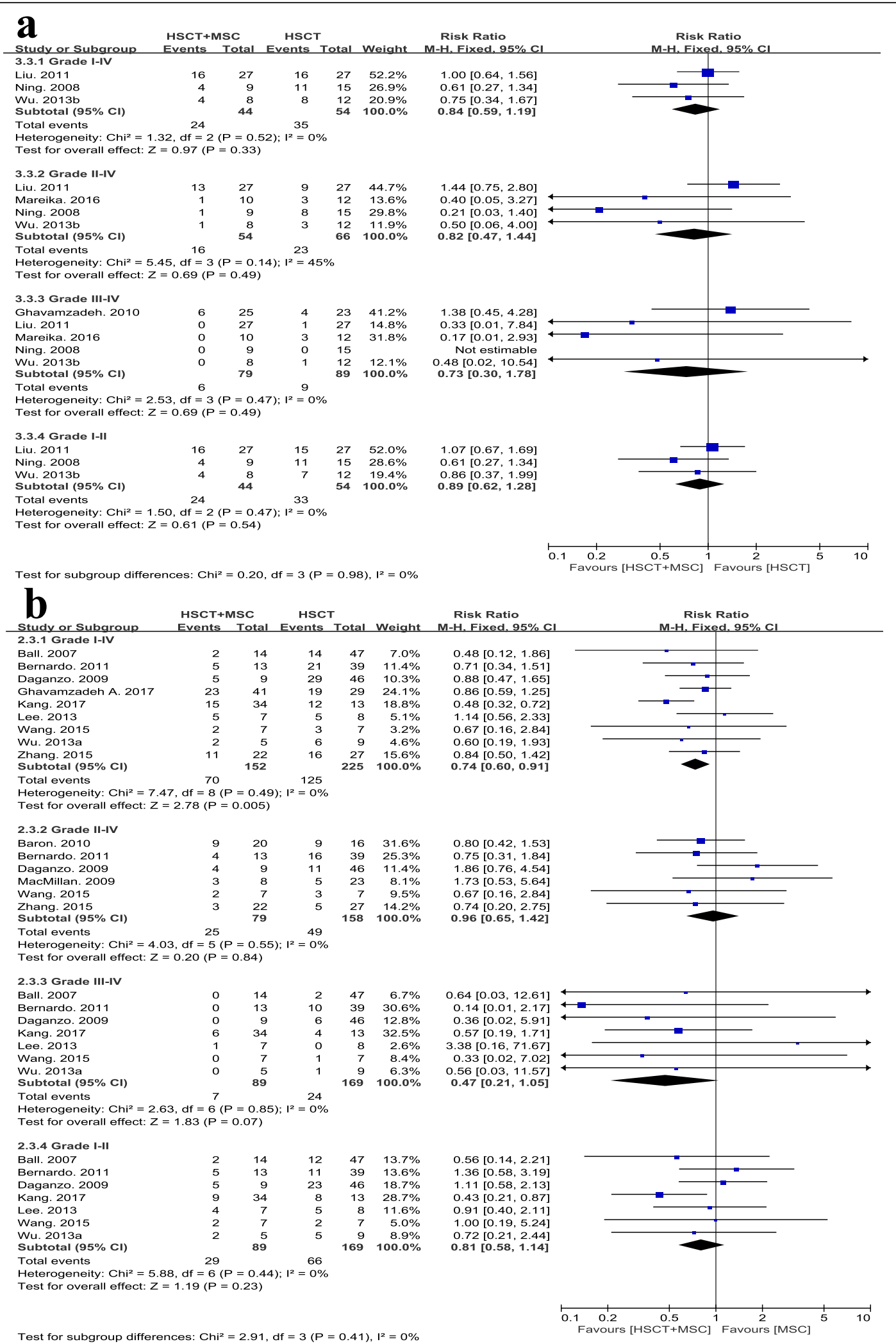

Fig. 4 Assessment of overall and graded incidence of aGVHD between HSCT+MSC group and HSCT alone group. Analysis was performed for a RCTs and $\mathbf{b}$ nRCTs separately 


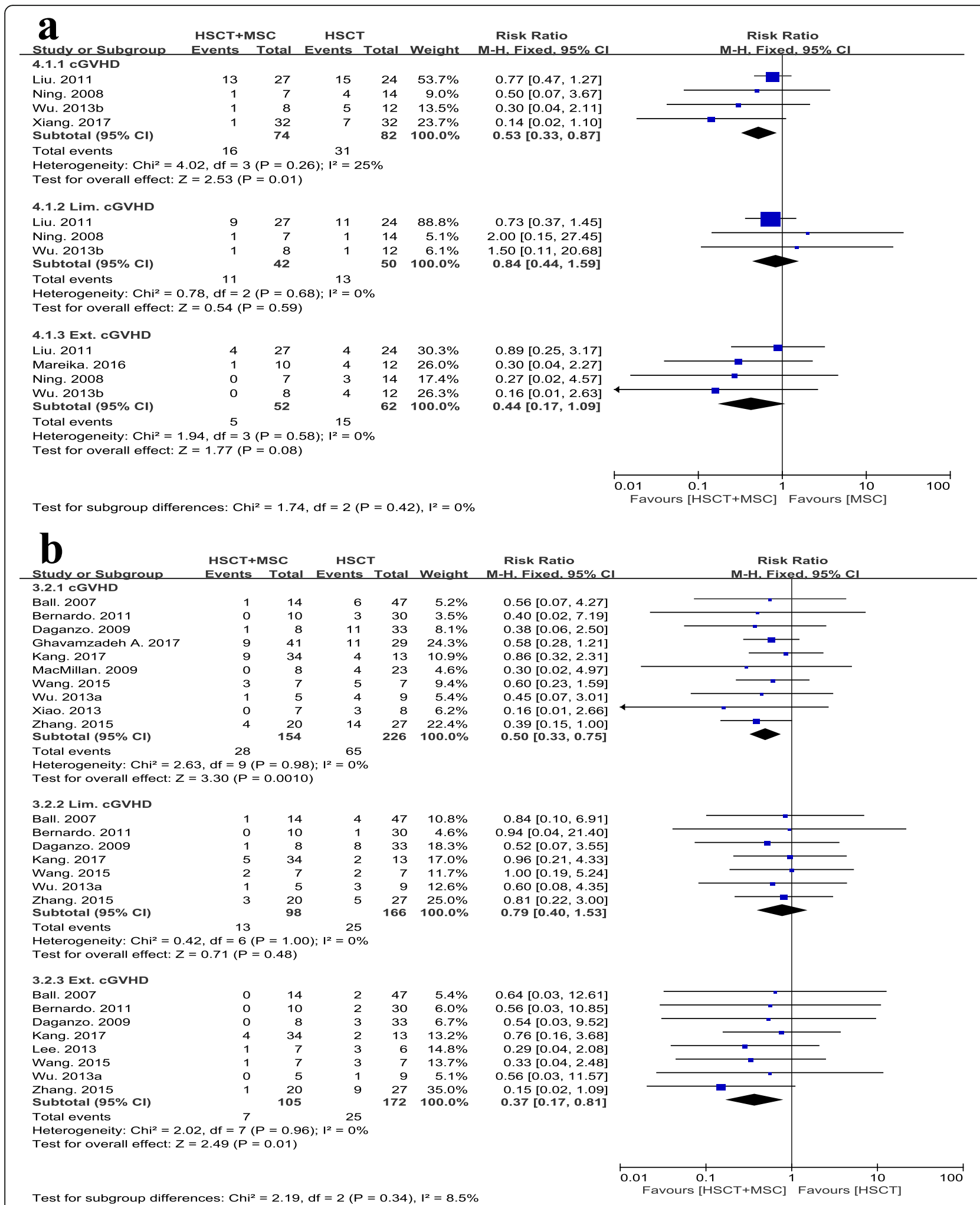

Fig. 5 Assessment of overall and graded incidence of CGVHD between HSCT+MSC group and HSCT alone group. Analysis was performed for a RCTs and $\mathbf{b} n R C T$ s separately. Lim., limited; Ext., extensive 


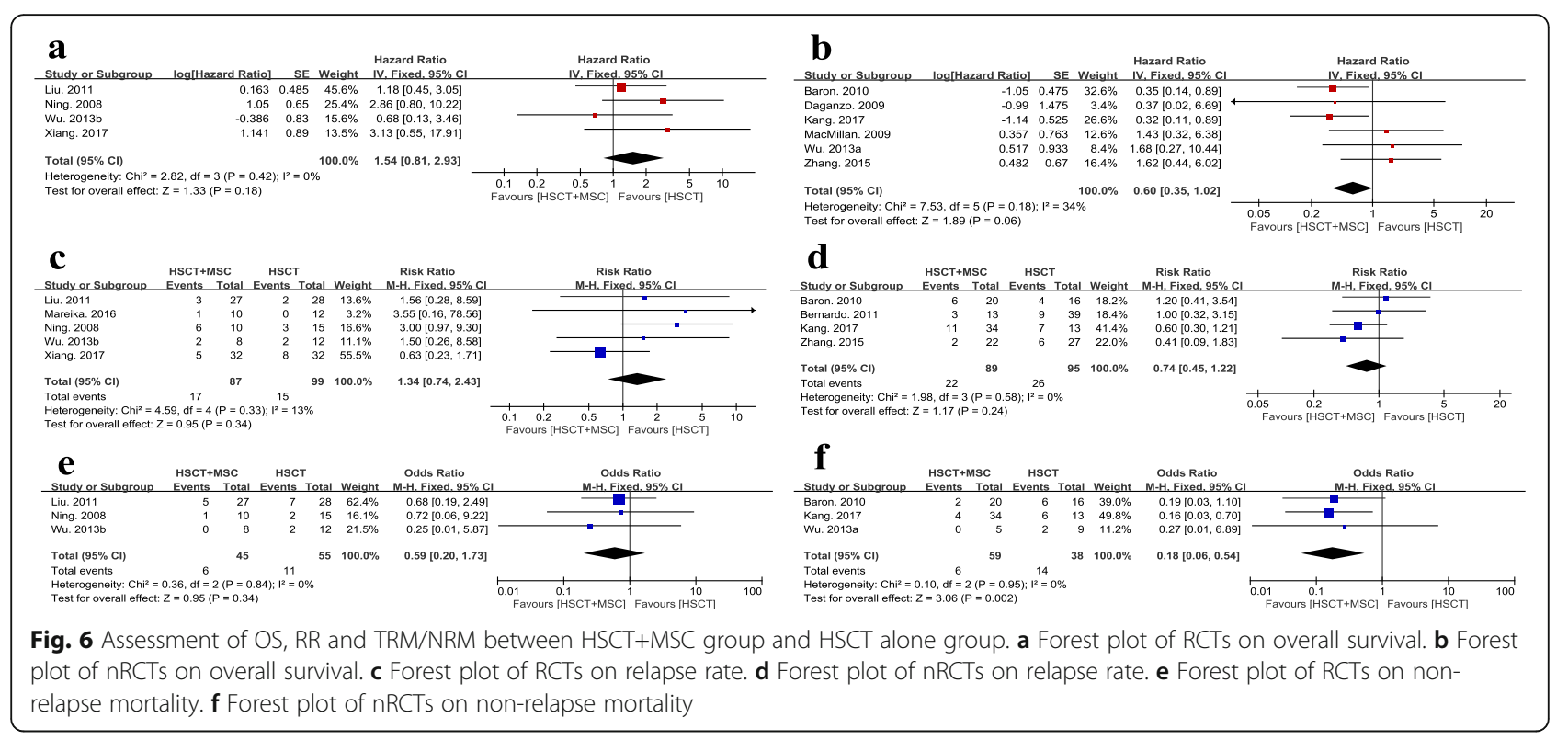

\section{Analyses of patient subgroups}

Finally, we conducted subgroup analyses based on the type of disease (malignant versus non-malignant), HLA matching (HLA-identical versus non-identical), and average age (children and adolescents versus adults) by combining all the RCTs and nRCTs together (detailed forest plots are presented in Additional files 7, 8, 9, 10, 11, 12, 13; summarized results are shown in Table 6).

For patients with malignancies, the risks of developing aGVHD (RR 0.77, 95\% CI 0.63 to $0.95, p=0.02$, Fig. S7a), cGVHD (RR $0.51,95 \%$ CI 0.35 to $0.75, p<0.01$, Fig. S8a), and NRM (OR 0.34, 95\% CI 0.16 to $0.73, p<$ 0.01 , Fig. S11a) were significantly reduced in the MSC co-transplantation group. For patients with nonmalignant blood diseases, MSC co-transplantation accelerated hematopoietic recovery in terms of both neutrophil and platelet engraftment (SMD $-2.09,95 \% \mathrm{CI}-$ 3.47 to $-0.70, p<0.01$, Fig. S5a; SMD $-1.64,95 \%$ CI 2.15 to $-1.14, p<0.01$, Fig. S6a; respectively).

Recipients receiving HLA-identical HSCT benefited in terms of the outcome of cGVHD (RR 0.43 , 95\% CI 0.22 to $0.84, p=0.01$, Fig. S8b) from MSC co-transplantation but had a lower OS (HR 2.95, 95\% CI 1.05 to 8.25, $p=$ 0.04, Fig. S9b). For patients who received HLA nonidentical HSCT, MSC co-transplantation exerted a significant positive effect on the outcomes of hematopoietic reconstitution (SMD $-0.63,95 \% \mathrm{CI}-1.18$ to $-0.07, p=$ 0.03 , Fig. S5b; SMD $-0.50,95 \%$ CI -0.93 to $-0.07, p=$ 0.02 , Fig. S6b; neutrophil and platelet engraftment, respectively) and significantly reduced the risk of developing GVHD (RR 0.76, 95\% CI 0.61 to $0.94, p=0.01$, Fig. S7b; RR 0.56, 95\% CI 0.39 to $0.81, p<0.01$, Fig. S8b; aGVHD and cGVHD respectively) and TRM/NRM (OR $0.31,95 \%$ CI 0.14 to $0.68, p<0.01$, Fig. S11b).
Adults who received MSC co-transplantation showed a lower incidence of cGVHD (RR 0.54, 95\% CI 0.36 to $0.81, p<0.01$, Fig. S8c) than those who did not. Among children and adolescents, MSC cotransplantation obviously improved hematopoietic reconstitution (SMD $-1.07,95 \% \mathrm{CI}-1.84$ to $-0.31, p<0.01$, Fig. S5c; SMD $-0.71,95 \%$ CI -1.22 to $-0.19, p<0.01$, Fig. S6c; neutrophil and platelet engraftment, respectively) and reduced the risk of developing GVHD (RR 0.64, 95\% CI 0.47 to $0.87, p<0.01$, Fig. S7c; RR $0.43,95 \%$ CI 0.23 to $0.84, p=0.01$, Fig. S8c; aGVHD and cGVHD, respectively) and TRM/NRM (OR $0.19,95 \%$ CI 0.05 to $0.68, p=0.01$, Fig. S11c).

\section{Discussion}

Allo-HSCT is the curative modality for many hematological diseases, and the optimization of the whole process is an important project. The main objective of our study was to determine whether MSC cotransplantation with allo-HSCT in patients with hematological conditions could improve transplantation outcomes. The results of our meta-analyses (shown in Table 5) indicated that MSC co-transplantation generally facilitates the engraftment of neutrophils and platelets and reduces the risk of cGVHD incidence but does not alter the risk of mortality or relapse, with a slightly positive trend towards reducing the risk of aGVHD incidence and NRM. These findings corroborated the findings of previous preclinical studies that MSCs, as progenitor cells of bone marrow stroma, enhanced HSC engraftment [44] and prevented lethal GVHD through immune modulation $[45,46]$ when co-transplanted with allo-HSCT in animal models. Based on the results of our subgroup analyses, co-transplantation of MSCs appears 
Table 5 Meta-analysis of the safety and efficacy of MSCs co-infused in allo-HSCT

\begin{tabular}{|c|c|c|c|c|c|c|c|}
\hline Outcome & Study design & Number of Trials & Sample size & SMD/RR/OR/HR & $95 \% \mathrm{Cl}$ & $P$ & $I^{2}$ \\
\hline \multirow[t]{2}{*}{$\overline{\mathrm{ANC}}$} & RCTs & 4 & 130 & SMD, -1.20 & $-2.32,-0.08$ & $0.04^{*}$ & $86 \%{ }^{\#}$ \\
\hline & $\mathrm{nRCTs}$ & 10 & 341 & $S M D,-0.54$ & $-1.05,-0.03$ & $0.04^{*}$ & $74 \%{ }^{\#}$ \\
\hline \multirow[t]{2}{*}{ PLT } & RCTs & 4 & 157 & SMD, -0.60 & $-1.17,-0.02$ & $0.04^{*}$ & $63 \%{ }^{\#}$ \\
\hline & $\mathrm{nRCTs}$ & 10 & 381 & $S M D,-0.70$ & $-1.24,-0.16$ & $0.01^{*}$ & $79 \%{ }^{\#}$ \\
\hline \multirow[t]{2}{*}{ aGVHD } & $\mathrm{RCTS}$ & 3 & 98 & $\mathrm{RR}, 0.84$ & $0.59,1.19$ & 0.33 & $0 \%$ \\
\hline & $\mathrm{nRCTs}$ & 9 & 377 & RR, 0.74 & $0.60,0.91$ & $0.005^{*}$ & $0 \%$ \\
\hline \multirow[t]{2}{*}{ cGVHD } & RCTs & 4 & 156 & $R R, 0.53$ & $0.33,0.87$ & $0.01^{*}$ & $25 \%$ \\
\hline & $\mathrm{nRCTs}$ & 10 & 380 & $\mathrm{RR}, 0.50$ & $0.33,0.75$ & $0.001^{*}$ & $0 \%$ \\
\hline \multirow[t]{2}{*}{ OS } & RCTs & 4 & 164 & $H R, 1.54$ & $0.81,2.93$ & 0.18 & $0 \%$ \\
\hline & $\mathrm{nRCTs}$ & 6 & 231 & $H R, 0.60$ & $0.35,1.02$ & 0.06 & $34 \%$ \\
\hline \multirow[t]{2}{*}{$\mathrm{RR}$} & RCTs & 5 & 186 & $\mathrm{RR}, 1.34$ & $0.74,2.43$ & 0.34 & $13 \%$ \\
\hline & $\mathrm{nRCTs}$ & 4 & 184 & $\mathrm{RR}, 0.74$ & $0.45,1.22$ & 0.24 & $0 \%$ \\
\hline \multirow[t]{2}{*}{ NRM } & RCTs & 3 & 100 & OR, 0.59 & $0.20,1.73$ & 0.34 & $0 \%$ \\
\hline & $\mathrm{nRCTs}$ & 3 & 97 & OR, 0.18 & $0.06,0.54$ & $0.002^{*}$ & $0 \%$ \\
\hline
\end{tabular}

*The difference was statistical significance

\#Significant heterogeneity needed to conduct subgroup analysis

to be an optimal treatment strategy for children and adolescents who receive HLA non-identical HSCT. Notably, in the subgroup of HLA-identical transplants recipients, the OS rate was significantly lower in recipients of MSC co-infusion than in those without the MSC co-infusion, and both of the included studies were conducted in patients with hematological malignancies [13, 24]. Thus, we should be cautious about relapse when considering whether to use MSCs in patients with hematological malignancies who are receiving HALidentical HSCT, although this evidence is based on limited studies (Table 6).

In addition to the therapeutic effect of intensive chemoradiotherapy, the potent GVL effects mediated by donor immunity also attribute to the success of alloHSCT in patients with hematological malignancies [47]. Compared with other HLA-matched transplants, patients receiving HLA-identical HSCT have a much lower incidence of rejection or GVHD and exhibit weaker GVL effects [47, 48], which might be further suppressed by infused MSCs, thus possibly leading to a higher risk of relapse [47]. The tumor-related effects of MSCs on hematological malignancies are not well understood [3]. Among multiple preclinical studies, some reported proliferative activity [49], while others suggested inhibitory effects [3]. For instance, MSCs were found to exert an antitumor effect on leukemic cells through extracellular vesicle, which contain various molecules, such as proteins, microRNA, mRNA, and siRNA, from their parental cells, and all these molecules can be transferred to cancer cells [3, 50]. Another study [49] reported a contradictory effect of human MSCs on tumor cell growth in vitro and in vivo. The animal study showed that human MSCs enhanced tumor formation and growth, which may be related to the increase in tumor vessel formation, while the in vitro study revealed that cocultured human MSCs inhibited the proliferation and induced the apoptosis of tumor cells [49]. Currently, the predominant hypothesis is that MSCs function as a "double-edged sword" through signaling pathways to suppress cancerous cell proliferation and apoptosis $[3,51]$.

A 20-year-old female patient with acute myeloid leukemia showed rapid engraftment and no acute or chronic GVHD after receiving haploidentical peripheral blood stem cells combined with MSCs [52]. The patient was doing well 31 months after the allo-HSCT, indicating an encouraging efficacy of MSCs co-transplanted with HLA-haploidentical HSCT in young people with blood malignancies. Recently, a multicenter clinical trial [53] also documented the efficacy and safety of infusing BM-MSCs combined with haplo-HSCT in children with SAA because this approach promoted hematopoietic implantation, protected against severe aGVHD and prevented cGVHD. All these clinical findings were consistent with our results.

A previous meta-analysis [18] that evaluated the role of MSC co-transplantation in allo-HSCT in 309 participants did not reveal any statistically significant effects. In addition to the 3 RCTs and 6 nRCTs included in the previous meta-analysis, we also included an additional 3 RCTs [13, 27, 29] and 7 nRCTs [30, 31, 35-39], with a total of 728 participants because of time reasons and the inclusion of Chinese articles. With much larger sample sizes and recently published studies, the results of our meta-analysis may be more reliable. In addition, our 


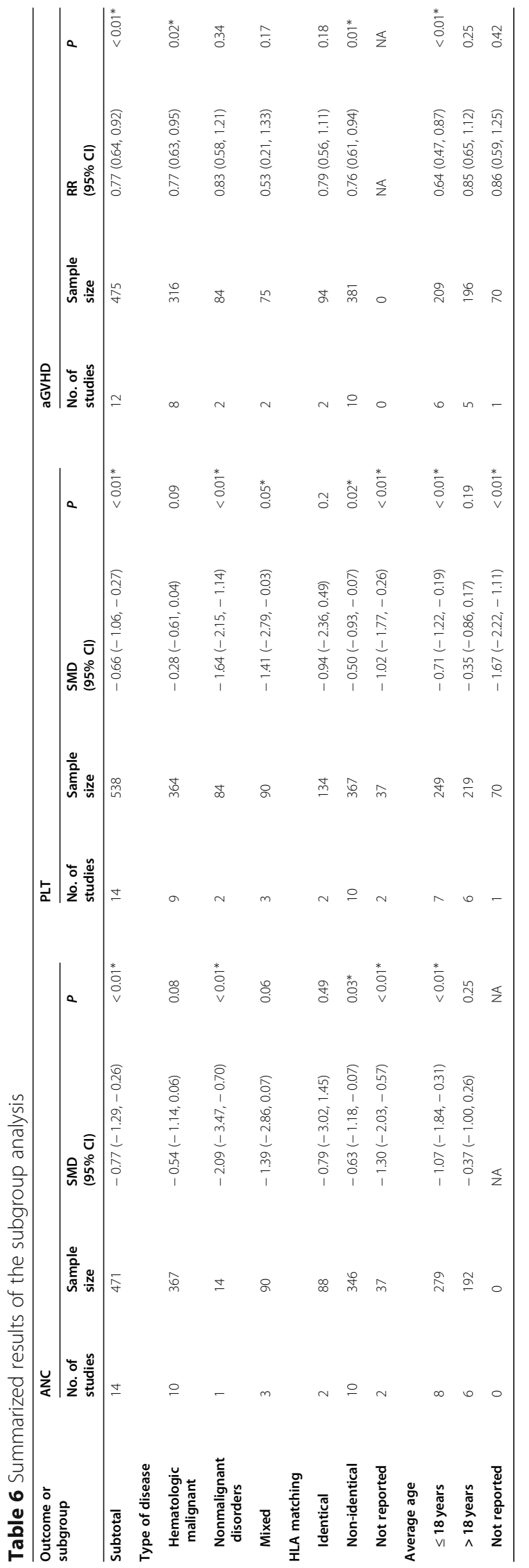




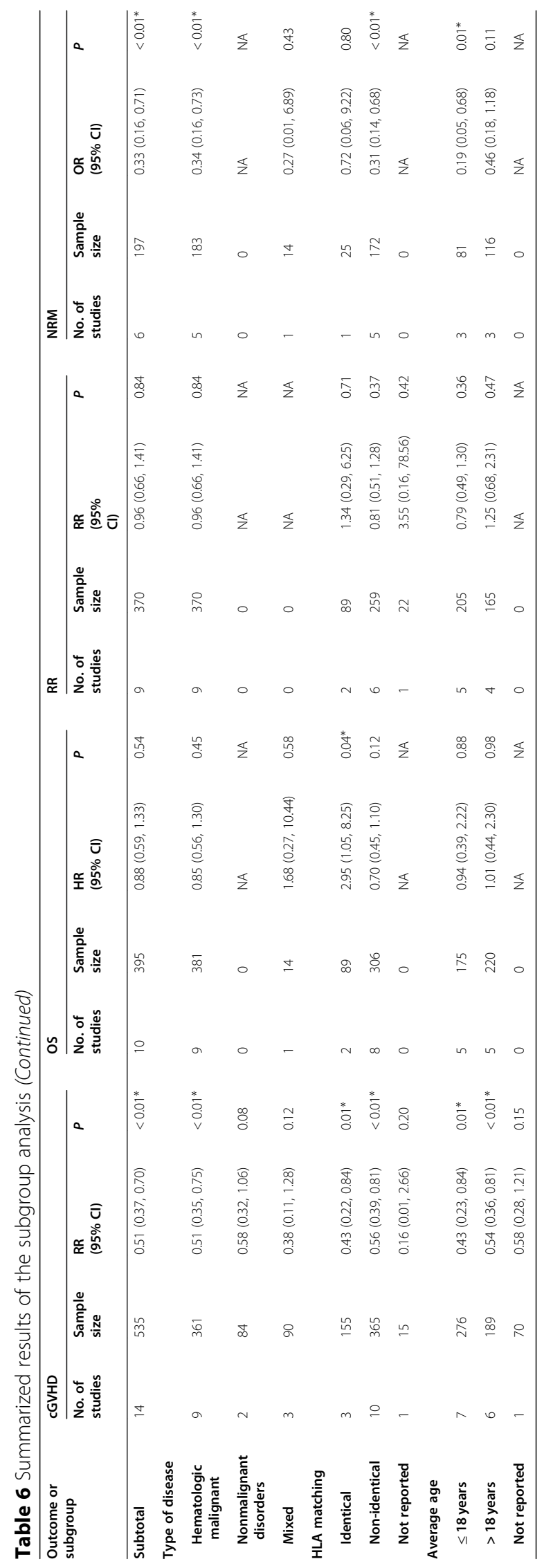


meta-analysis reported more outcomes, including PLT engraftment, OS, and RR. Furthermore, we performed subgroup analyses according to the patients' disease, age, and HLA-matching. Two relevant meta-analyses $[19,54]$ pooled studies in which MSCs were co-transplanted with HSCs and MSCs were infused post the transplantation of HSCs, mainly to explore the prophylactic efficacy of MSCs for GVHD. Zhao et al. [54] categorized the studies of Liu et al. [22] and Xiang [13] into subgroup of after infusion, leaving only 2 trials $[24,28]$ in the coinfusion subgroup. Compared with results from this coinfusion subgroup analysis, our meta-analysis appears to be more powerful due to the adequate number of included studies. Wang et al. [19] did not observe a significant difference in the outcome of cGVHD (RR 0.52, 95\% CI 0.24 to $1.14, p=0.259$, participants $=156)$ in the subgroup of MSC co-infused, which was possibly attributed to the adoption of the random effects model. With an $I^{2}$ score of $25 \%$, we employed a fixed-effects model for our study. Consequently, by analyzing the same 4 RCTs that were included in the meta-analysis by Wang, our results indicated that MSC co-infusion significantly reduced the incidence of cGVHD (RR $0.53,95 \%$ CI 0.33 to $0.87, p=$ 0.01 , participants $=156)$. Furthermore, our meta-analysis of 10 other nRCTs (RR $0.50,95 \%$ CI 0.33 to $0.75, p<$ 0.01 , participants $=380$ ) yielded consistent results. In addition to CGVHD and OS, we evaluated more outcomes, including ANC and PLT engraftment, aGVHD, and immune recovery. Overall, regarding the safety and efficacy of MSCs co-transplanted in allo-HSCT recipients, our study provided more comprehensive and robust evidence than previous similar meta-analyses.

In addition to the patient's condition, more knowledge of MSCs, such as the tissue source and immunogenicity of MSCs, dose, routes of delivery, and infusion timing of MSCs, should improve the overall therapeutic efficacy and potency of MSC co-transplantation in allo-HSCT. Although most of the clinical information published to date has been produced using culture-expanded marrow-derived MSCs, some information shows that MSCs from BM, UC, adipose tissue, and placenta possess a similar functional potential $[9,55-57]$, indicating that the antitumor effect of MSCs may not depend on their tissue source and origin [9]. Another single-cell RNA sequencing study of equine MSCs revealed both inter- and intra-source heterogeneity across different sources of MSCs, indicating that some MSC subgroups may have advantageous biological functions [58]. It was reported that UC-derived MSCs exerted superior prophylactic effects against cGVHD than did BM-MSCs [19]. However, even after multiple administrations, human allogeneic MSCs do not trigger a strong immune response that causes rejection [9]. Regardless of conventional graft-versus-host compatibility considerations, this ultimate immune rejection of donor MSCs does not affect the clinical efficacy of MSCs, as suggested by abundant preclinical and clinical studies in allogeneic MSCs [59].

MSCs exert their functions, such as proliferation, secreted factors, antitumor effects, and cytotoxicity, in a dose-dependent manner [60], suggesting that MSCs produce a better effect when administered at relatively high doses $[19,60]$. According to previous studies, high doses of MSCs are inhibitory in mixed lymphocyte cultures, while low doses promote lymphocyte proliferation [48]. However, this dose-response effect may not be beneficial when the MSC dose is above a certain threshold [60, 61]. Numerous routes of MSC delivery to the human body have been used, including intramuscular or direct injection into tissues or organs [62, 63], intravenous (IV) infusion [63-65], intraarterial (IA) infusion [63, 66], and intra-bone marrow injection $[67,68]$. Topical application of MSCs has been widely used in burn medicine and wound care [63]. In the field of transplantation, the IV injection of MSCs is the most common method to apply MSCs [63]. However, this approach might result in a large number of MSCs being trapped in the lungs and a limited number of cells reaching the arterial system [65]. In addition, IV infusion may facilitate the rapid clearance of clinical MSCs by innate host immune cells [63]. Researchers have questioned whether the remaining number of cells homing to the bone marrow could produce therapeutic effect. By inhibiting MSC CD49 or administrating 2 boluses instead of a single bolus, pulmonary MSC passages were increased significantly following IV infusion [65]. Considerations specific to IV delivery concern cells generating emboli or clots [63]. IA infusion of MSCs allows mass cells to home to the bone marrow to produce therapeutic effects, and improved engraftment efficiency has been observed in previous studies [69]. However, the IA delivery of MSCs for stroke is associated with a potential risk of cerebral infarction caused by microembolisms and decreased cerebral blood flow, according to a survey of published results [66]. Although the intra-bone marrow injection of whole BM cells (both pluripotent HSCs and MSCs) was thought to be a valuable strategy for allogeneic stem cell transplantation [67], no major conclusions have been reached regarding the optimal method for MSC delivery [63].

The timing and duration of MSC infusion is another important factor to consider when evaluating the therapeutic efficacy of MSCs in allo-HSCT. Our research shows that MSC co-transplantation significantly improved the engraftment of both neutrophils and platelets and reduced the risk of cGVHD incidence. Similar effects were also observed in the subgroup in which MSCs were infused after HSCT, as reported in a previous meta-analysis [54]. Although no significant beneficial 
effects of MSCs were observed in the subgroup in which MSCs were infused before HSCT [54], this is probably because both of the included studies were performed in patients with hematological malignancies along with the limited statistical effect caused by the small number of studies and sample sizes. Regarding the duration of the MSC infusion, some investigators have suggested that the infusion should last for 30 min or more [24, 34]. Another study reported that MSCs were infused at a rate of $5 \mathrm{~mL} / \mathrm{min}$ [31]. Compared with fresh MSCs, MSCs subjected to freezing and thawing display increased activation of the instant blood-mediated inflammatory reaction and susceptibility to complement-mediated lysis, exerting smaller immunomodulatory effects [63, 70]. Thus, upon systemic infusion, fresh MSCs are more effective in the clinic than freeze-thawed MSCs [63].

Another important safety concern in MSC therapy is their procoagulant effects after blood contact, as suggested by a large number of in vitro studies [63]. Therefore, we must highlight the importance of monitoring thrombotic events after the MSC infusion, especially in patients who have acquired hypercoagulability or are at high risk of thrombosis due to their primary disease process [63]. In a word, one size does not fit all. The use of MSCs and the precise regimens of MSCs used in alloHSCT depend on the specific clinical condition of patients. Further studies of MSC science and their therapeutic potential are needed. We conducted this study based on the assumption that MSC co-transplantation in allo-HSCT would be a highly effective treatment approach and/or an early therapeutic intervention with clear prognostic benefits for patients with hematological diseases, particularly hematological malignancies. In these cases, the inclusion of genetic information such as single nucleotide polymorphisms into the prediction and diagnosis of hematological malignancies may be of high clinical value. In addition to predicting the occurrence of such diseases and guiding the judgment of curative effect after treatment, the application of genetic data may also rapidly improve the accuracy of diagnosis and reduce the number of patients diagnosed with false negative [71].

Several limitations exist in this study. First, heterogeneity across studies, including the types and stages of diseases, sources and dosage of HSCs and MSCs, HLA matching, definitions of outcomes, varying follow-up times, and study designs, was notable, although we performed subgroup and sensitivity analyses to attempt to resolve the heterogeneity. Additionally, in the subgroups of non-malignant disorders and HLA-identical matching, no more than 3 trials were included in each metaanalysis. Second, publication bias was possible because of the 4 trials (ChiCTR-OCN-15006595, ChiCTR-IIR16007806, NCT01092026; NCT00081055) [72-75], which were completed but we failed to find any related publications. Third, we restricted the language of the literature search to only Chinese and English, which may result in a failure to retrieve some potentially relevant studies. Fourth, 3 trials [27, 29, 39], which were published in the form of abstracts in poster sessions, did not provide us with sufficient information to fully assess the source of the bias. Last, the limitations of the $I^{2}$ test must be considered. Although most of the $I^{2}$ test scores were less than $50 \%$, the $I^{2}$ values are likely to be underestimated, particularly if a limited number of trials or a few events are assessed in a meta-analysis [76, 77].

\section{Conclusion}

Collectively, the treatment strategy of an MSC coinfusion with allo-HSCT generally improved engraftment and reduced the risk of developing cGVHD, without increasing the risk of mortality or relapse. In terms of aGVHD and NRM, the effect of the MSC co-infusion was not quite significant. Specifically, the data obtained support the application of MSCs co-transplanted with HLA-nonidentical HSCT in children and young individuals. Since the effects of MSCs on blood malignancies are not well understood, we do not recommend the use of MSCs co-transplanted with HLA-identical HSCT in adult patients with hematological malignancies based on the currently available data. In this meta-analysis, the number of studies conducted on patients with hematological malignancies undergoing HLA-identical HSCT is limited. Hence, additional in-depth assessments of the safety and efficacy of MSC co-transplantation in this population are recommended to avoid harming patients.

\section{Abbreviations}

allo-HSCT: Allogeneic hematopoietic stem cell transplantation; HSCs: Hematopoietic stem cells; MSCs: Mesenchymal stem cells; PRIS MA: Preferred Reporting Items for Systematic Reviews and Meta-Analysis; HLA: Human leukocyte antigen; GVL: Graft-versus-leukemia; BM: Bone marrow; UCB: Umbilical cord blood; SAA: Severe aplastic anemia; PB: Peripheral blood; aGVHD/cGVHD: Acute/chronic graft-versus-host disease; OS: Overall survival; RR: Relapse rate; NRM: Non-relapse mortality; RCTs: Randomized controlled trials; nRCTs: Non-randomized controlled trials; RoB: Risk of bias; SMD: Standardized mean difference; RR: Risk ratio; OR: Odds ratios; HR: Hazard ratio; SD: Standard deviation; Cls: Confidence intervals; ANC: Absolute neutrophil count; PLT: Platelet; DCs: Dendritic cells; NK cells: Natural killer cells; IV: Intravenous; IA: Intraarterial

\section{Supplementary Information}

Supplementary information accompanies this paper at https://doi.org/10. 1186/s13287-021-02304-X.

Additional file 1: Table S1. The Eligibility Criteria for included studies in systematic review.

Additional file 2: Text S1. Detailed search strategies.

Additional file 3: Fig. S1. Funnel plots of publication bias evaluating the effect of MSC co-infusion on (a) neutrophil engraftment and (b) platelet engraftment. 
Additional file 4: Fig. S2. Subset analysis based on the dosage of MSCs for outcomes of neutrophil engraftment ( $a \& b)$ and platelet engraftment (c\&d).

Additional file 5: Fig. S3. Funnel plots of publication bias evaluating the effect of MSC co-infusion on (a) aGVHD and (b) CGVHD.

Additional file 6: Fig. S4. Funnel plots of publication bias evaluating the effect of MSC co-infusion on (a) OS and (b) RR.

Additional file 7: Fig. S5. Assessment of neutrophil engraftment in subgroup analysis according to (a) type of disease, (b) HLA matching and (c) average age.

Additional file 8: Fig. S6. Assessment of platelet engraftment in subgroup analysis according to (a) type of disease, (b) HLA matching and (c) average age.

Additional file 9: Fig. S7. Assessment of aGVHD in subgroup analysis according to (a) type of disease, (b) HLA matching and (c) average age.

Additional file 10: Fig. S8. Assessment of CGVHD in subgroup analysis according to (a) type of disease, (b) HLA matching and (c) average age.

Additional file 11: Fig. S9. Assessment of OS in subgroup analysis according to (a) type of disease, (b) HLA matching and (c) average age.

Additional file 12: Fig. S10. Assessment of RR in subgroup analysis according to (a) type of disease, (b) HLA matching and (c) average age.

Additional file 13: Fig. S11. Assessment of NRM in subgroup analysis according to (a) type of disease, (b) HLA matching and (c) average age.

\section{Acknowledgements}

Not applicable

\section{Authors' contributions}

SNX and LHW were responsible for the conception, design, and supervision of this study. SNX and TL contributed to the formulation of retrieval strategies, the search and selection of articles, risk of bias, performing the statistical analysis, and manuscript preparation. CXL and TL were responsible for selecting articles, extracting data, and data conversion. JSZ, LW, WS, QX, $Y L$, and $Y L Z$ participated in the data checking and interpretation, illustration making, and manuscript preparation. CXL, SNX, and TL involved in revising the manuscript critically for important intellectual content. All authors were responsible for drafting the manuscript and read and approved the final version.

\section{Funding}

This work was supported by the Project from Army Medical University (2017XQN11). The funding had no role in the study design, data collection, data analysis, data interpretation, or manuscript writing.

\section{Availability of data and materials}

All supporting data and materials were included in the article and its additional files.

\section{Declarations}

\section{Ethic approval and consent to participate}

Not applicable.

\section{Consent for publication}

Not applicable.

\section{Competing interests}

The authors declare that they have no competing interests.

\section{Author details}

${ }^{1}$ Center for Hematology, Southwest Hospital, Army Medical University (Third Military Medical University), \#30 Gaotanyan Street, Shapingba District, Chongqing 400038, People's Republic of China. ${ }^{2}$ Admin Office of Southwest Hospital, Army Medical University (Third Military Medical University), \#30 Gaotanyan Street, Shapingba District, Chongqing 400038, People's Republic of China. ${ }^{3}$ Teaching-Research Office of Nursing, Southwest Hospital, Army Medical University (Third Military Medical University), Chongqing, People's
Republic of China. ${ }^{4}$ School of Nursing, Army Medical University (Third Military Medical University), Chongqing, People's Republic of China.

Received: 4 February 2021 Accepted: 22 March 2021

Published online: 20 April 2021

\section{References}

1. Copelan EA, Chojecki A, Lazarus HM, Avalos BR. Allogeneic hematopoietic cell transplantation; the current renaissance. Blood Rev. 2019:34:34-44 https://doi.org/10.1016/j.blre.2018.11.001.

2. Kim EJ, Kim N, Cho SG. The potential use of mesenchymal stem cells in hematopoietic stem cell transplantation. Exp Mol Med. 2013;45(1):e2 https:// doi.org/10.1038/emm.2013.2.

3. Fathi E, Sanaat Z, Farahzadi R. Mesenchymal stem cells in acute myeloid leukemia: a focus on mechanisms involved and therapeutic concepts. Blood Res. 2019;54(3):165-74 https://doi.org/10.5045/br.2019.54.3.165.

4. Varma MJ, Breuls RG, Schouten TE, et al. Phenotypical and functional characterization of freshly isolated adipose tissuederived stem cells. Stem Cells Dev. 2007;16(1):91-104 https://doi.org/10.1089/scd.2006.0026.

5. Diehl R, Ferrara F, Müller C, Dreyer AY, McLeod DD, Fricke S, et al. Immunosuppression for in vivo research: state-of-the-art protocols and experimental approaches. Cell Mol Immunol. 2017;14(2):146-79 https://doi. org/10.1038/cmi.2016.39

6. Gholizadeh-Ghaleh Aziz S, Fathi E, Rahmati-Yamchi M, Akbarzadeh A Fardyazar Z, Pashaiasl M. An update clinical application of amniotic fluidderived stem cells (AFSCs) in cancer cell therapy and tissue engineering. Artif Cells Nanomed Biotechnol. 2017:45(4):765-74 https://doi.org/10.1 080/21691401.2016.1216857.

7. Fathi E, Valipour B, Charoudeh HN, Farahzadi R. Interleukin-6, -8 , and TGF- $\beta$ secreted from Mesenchymal stem cells show functional role in reduction of telomerase activity of leukemia cell via Wnt5a/ $\beta$-catenin and P53 pathways. Adv Pharm Bull. 2020;10(2):307-14 https://doi.org/10.34172/apb.2020.037.

8. Wu KH, Wu HP, Chan CK, Hwang SM, Peng CT, Chao YH. The role of mesenchymal stem cells in hematopoietic stem cell transplantation: from bench to bedsides. Cell Transplant. 2013;22(4):723-9 https://doi.org/10.3727/ $096368912 \times 655217$.

9. Caplan Al, Correa D. The MSC: an injury drugstore. Cell Stem Cell. 2011;9(1): 11-5 https://doi.org/10.1016/j.stem.2011.06.008.

10. Manabe A, Coustan-Smith E, Behm FG, Raimondi SC, Campana D. Bone marrow-derived stromal cells prevent apoptotic cell death in B-lineage acute lymphoblastic leukemia. Blood. 1992;79(9):2370-7 https://doi.org/10.11 82/blood.V79.9.2370.2370.

11. Ahn JO, Coh YR, Lee HW, Shin IS, Kang SK, Youn HY. Human adipose tissuederived mesenchymal stem cells inhibit melanoma growth in vitro and in vivo. Anticancer Res. 2015;35(1):159-68.

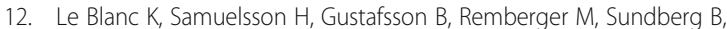
Arvidson J, et al. Transplantation of mesenchymal stem cells to enhance engraftment of hematopoietic stem cells. Leukemia. 2007;21(8):1733-8 https://doi.org/10.1038/sj.leu.2404777.

13. Xiang JF. Effect of human umbilical cord mesenchymal stem cells on immune reconstruction of acute lymphoblastic leukemia children undergoing allogeneic hematopoietic stem cell transplantation. Chin J Tissue Eng Res. 2017;21(29):4679-84 in Chinese.

14. Lee SH, Lee MW, Yoo KH, Kim DS, Son MH, Sung KW, et al. Cotransplantation of third-party umbilical cord blood-derived MSCs promotes engraftment in children undergoing unrelated umbilical cord blood transplantation. Bone Marrow Transplant. 2013;48(8):1040-5 https://doi.org/1 0.1038/bmt.2013.7

15. Bernardo ME, Ball LM, Cometa AM, Roelofs H, Zecca M, Avanzini MA, et al. Co-infusion of ex vivo-expanded, parental MSCs prevents life-threatening acute GVHD, but does not reduce the risk of graft failure in pediatric patients undergoing allogeneic umbilical cord blood transplantation. Bone Marrow Transplant. 2011;46(2):200-7 https://doi.org/10.1038/bmt.2010.87.

16. Ball LM, Bernardo ME, Roelofs $H$, Lankester A, Cometa A, Egeler RM, et al. Cotransplantation of ex vivo expanded mesenchymal stem cells accelerates lymphocyte recovery and may reduce the risk of graft failure in haploidentical hematopoietic stem-cell transplantation. Blood. 2007;110(7): 2764-7 https://doi.org/10.1182/blood-2007-04-087056.

17. Yue C, Ding Y, Gao Y, Li L, Pang Y, Liu Z, et al. Cotransplantation of haploidentical hematopoietic stem cells and allogeneic bone marrowderived mesenchymal stromal cells as a first-line treatment in very severe 
aplastic anemia patients with refractory infections. Eur J Haematol. 2018; 100(6):624-9 https://doi.org/10.1111/ejh.13060.

18. Kallekleiv M, Larun L, Bruserud $\varnothing$, Hatfield KJ. Co-transplantation of multipotent mesenchymal stromal cells in allogeneic hematopoietic stem cell transplantation: a systematic review and meta-analysis. Cytotherapy. 2016;18(2):172-85 https://doi.org/10.1016/j.jcyt.2015.11.010.

19. Wang L, Zhu CY, Ma DX, Gu ZY, Xu CC, Wang FY, et al. Efficacy and safety of mesenchymal stromal cells for the prophylaxis of chronic graft-versushost disease after allogeneic hematopoietic stem cell transplantation: a meta-analysis of randomized controlled trials. Ann Hematol. 2018;97(10): 1941-50 https://doi.org/10.1007/s00277-018-3384-8.

20. Moher D, Shamseer L, Clarke M, Ghersi D, Liberati A, Petticrew M, et al. Preferred reporting items for systematic review and meta-analysis protocols (PRISMA-P) 2015 statement. Sys Rev. 2015;4(1):1 https://doi.org/10.1186/204 6-4053-4-1.

21. Xu S, Li X, Zhang J, Chen J. Prognostic value of CD56 in patients with acute myeloid leukemia: a meta-analysis. J Cancer Res Clin Oncol. 2015;141(10): 1859-70 https://doi.org/10.1007/s00432-015-1977-3.

22. Liu K, Chen Y, Zeng Y, Xu L, Liu D, Chen H, et al. Coinfusion of mesenchymal stromal cells facilitates platelet recovery without increasing leukemia recurrence in haploidentical hematopoietic stem cell transplantation: a randomized, controlled clinical study. Stem Cells Dev. 2011;20(10):1679-85 https://doi.org/10.1089/scd.2010.0447.

23. Cho BS, Min CK, Eom KS, Kim YJ, Kim HJ, Lee S, et al. Feasibility of NIH consensus criteria for chronic graft-versus-host disease. Leukemia. 2009; 23(1):78-84 https://doi.org/10.1038/leu.2008.276.

24. Ning $H$, Yang $F$, Jiang $M, H u L$, Feng $K$, Zhang J, et al. The correlation between cotransplantation of mesenchymal stem cells and higher recurrence rate in hematologic malignancy patients: outcome of a pilot clinical study. Leukemia. 2008;22(3):593-9 https://doi.org/10.1038/sj.leu.2405090

25. Elfeky R, Lazareva A, Qasim W, Veys P. Immune reconstitution following hematopoietic stem cell transplantation using different stem cell sources. Expert Rev Clin Immunol. 2019;15(7):735-51 https://doi.org/10.1080/1744 666X.2019.1612746.

26. McCurdy SR, Luznik L. Immune reconstitution after T-cell replete HLAhaploidentical transplantation. Semin Hematol. 2019:56(3):221-6 https://doi. org/10.1053/j.seminhematol.2019.03.005.

27. Ghavamzadeh A, Alimoghaddam K, Hamidieh AA, Karimi A, Bashtar M, Shamshiri AR. CO-transplantation of HLA-matched related donors cultureexpanded mesenchymal stromal cells and hematopoietic stem cells in thalassemia major patients. Biol Blood Marrow Transplant. 2010;16(2):S214 https://doi.org/10.1016/j.bbmt.2009.12.183.

28. Wu KH, Tsai C, Wu HP, Sieber M, Peng CT, Chao YH. Human application of ex vivo expanded umbilical cord-derived mesenchymal stem cells: enhance hematopoiesis after cord blood transplantation. Cell Transplant. 2013;22(11): 2041-51 https://doi.org/10.3727/096368912X663533.

29. Mareika I, Shman T, Isaikina Y, Minakovskaya N, Aleinikova O. Influence of mesenchymal stem cells co-transplantation on post-transplant period after allogeneic hematopoietic cell transplantation in children with acute leukemia. Bone Marrow Transplant. 2016;51(1):S118-9.

30. Gonzalo-Daganzo R, Regidor C, Martin-Donaire T, Rico MA, Bautista G, Krsnik I, et al. Results of a pilot study on the use of third-party donor mesenchymal stromal cells in cord blood transplantation in adults. Cytotherapy. 2009;11(3):278-88 https://doi.org/10.1080/14653240902807018.

31. Macmillan ML, Blazar BR, DeFor TE, Wagner JE. Transplantation of ex-vivo culture-expanded parental haploidentical mesenchymal stem cells to promote engraftment in pediatric recipients of unrelated donor umbilical cord blood: results of a phase I-II clinical trial. Bone Marrow Transplant. 2009;42(6):447-54.

32. Baron F, Lechanteur C, Willems E, Bruck F, Baudoux E, Seidel L, et al. Cotransplantation of mesenchymal stem cells might prevent death from graft-versus-host disease (GVHD) without abrogating graft-versus-tumor effects after HLA-mismatched allogeneic transplantation following nonmyeloablative conditioning. Biol Blood Marrow Transplant. 2010;16(6): 838-47 https://doi.org/10.1016/j.bbmt.2010.01.011.

33. Hou RQ, Wang J, Kong Y, Chen YH, Huang XJ, Zeng Y, et al. Transfusion of mesenchymal stem cells combined with haploidentical HSCT improves hematopoietic microenvironment. J Exp Hematol. 2010;18(1):155-60 in Chinese.

34. Wu KH, Sheu JN, Wu HP, Tsai C, Sieber M, Peng CT, et al. Cotransplantation of umbilical cord-derived mesenchymal stem cells promote hematopoietic engraftment in cord blood transplantation: a pilot study. Transplantation. 2013;95(5):773-7 https://doi.org/10.1097/TP.0b013e31827a93dd.
35. Xiao YN, Zhang X, LIU Y, Zhang GL, Zeng JZ, Miao YY, et al. The clinical application of umbilical cord blood mesenchymal stem cell in peripheral hematopoietic stem cell transplantation. Chin J Blood Transfus. 2013;026(4): 315-8 in Chinese.

36. Wang YJ, Li DL. Influence of the Effect of Umbilical Cord Derived Mesenchymal Stem Cells on Non-Identical Heterogenic Peripheral Hematopoietic Stem Cells Transplantation. Clin Misdiagn Misther. 2015;28(3):85-9 in Chinese.

37. Zhang XT, Duan LN, Ding L, Zhu L, Yan HM, Wang ZD, et al. Unrelated Donor Peripheral Blood Stem Cell Transplantation Combined with Umbilical Cord Mesenchymal Stem Cells in Patients with Hematologic Malignancies. J Exp Hematol. 2015;23(5):1445-50 in Chinese

38. Kang HZ, Zheng XL, Wang ZD, Han DM, Ding L, Yan HM, et al. Efficacy and Safety of Co-transplantation of Haploidentical-HSC with Umbilical Cord Mesenchymal Stem Cell in Children with Hematologic Malignancies. J Exp Hematol. 2017;25(4):1151-7 in Chinese.

39. Ghavamzadeh A, Ranjbar H, Nikbakht M, Alimoghaddam K, Vaezi M, Bahar B, et al. Outcomes of co-transplantation of mesenchymal stem cells and hematopoietic stem cells compared to hematopoietic stem cell transplantation alone in -thalassemia patients. Bone Marrow Transplant. 2017;52(1):S293.

40. Higgins JPT, Savović J, Page MJ, Elbers RG, Sterne JAC. Chapter 8: assessing risk of bias in a randomized trial. In: Higgins JPT, Thomas J, Chandler J, Cumpston M, Li T, Page MJ, Welch VA, editors. Cochrane handbook for systematic reviews of interventions version 6.0 (updated July 2019): Cochrane; 2019. Available from www.training.cochrane.org/handbook. Accessed 17 Jun 2020.

41. Luo D, Wan X, Liu J, Tong T. Optimally estimating the sample mean from the sample size, median, mid-range, and/or mid-quartile range. Stat Methods Med Res. 2018;27(6):1785-805 https://doi.org/10.1177/0962280216669183.

42. Tierney JF, Stewart LA, Ghersi D, Burdett S, Sydes MR. Practical methods for incorporating summary time-to-event data into meta-analysis. Trials. 2007 . 8(1):16 https://doi.org/10.1186/1745-6215-8-16.

43. Higgins JP, Thompson SG, Deeks JJ, Altman DG. Measuring inconsistency in meta-analyses. BMJ. 2003;327(7414):557-60 https://doi.org/10.1136/bmj.327. 7414.557.

44. Carrancio S, Romo C, Ramos T, Lopez-Holgado N, Muntion S, Prins HJ, et al. Effects of MSC coadministration and route of delivery on cord blood hematopoietic stem cell engraftment. Cell Transplant. 2013;22(7):1171-83 https://doi.org/10.3727/096368912X657431.

45. Tian Y, Deng YB, Huang YJ, Wang Y. Bone marrow-derived mesenchymal stem cells decrease acute graft-versus-host disease after allogeneic hematopoietic stem cells transplantation. Immunol Investig. 2008;37(1):29_ 42 https://doi.org/10.1080/08820130701410223.

46. Chung NG, Jeong DC, Park SJ, Choi BO, Cho B, Kim HK, et al. Cotransplantation of marrow stromal cells may prevent lethal graft-versushost disease in major histocompatibility complex mismatched murine hematopoietic stem cell transplantation. Int J Hematol. 2004;80(4):370-6 https://doi.org/10.1532/IJH97.A30409.

47. Singh AK, McGuirk JP. Allogeneic stem cell transplantation: a historical and scientific overview. Cancer Res. 2016;76(22):6445-51 https://doi.org/10.1158/ 0008-5472.CAN-16-1311.

48. Le Blanc K, Ringdén O. Immunobiology of human mesenchymal stem cells and future use in hematopoietic stem cell transplantation. Biol Blood Marrow Transplant. 2005;11(5):321-34 https://doi.org/10.1016/j.bbmt.2005.01.005.

49. Tian LL, Yue W, Zhu F, Li S, Li W. Human mesenchymal stem cells play a dual role on tumor cell growth in vitro and in vivo. J Cell Physiol. 2011; 226(7):1860-7 https://doi.org/10.1002/jcp.22511.

50. Lohan P, Treacy O, Griffin MD, Ritter T, Ryan AE. Anti-donor immune responses elicited by allogeneic mesenchymal stem cells and their extracellular vesicles: are we still learning? Front Immunol. 2017;8:1626 https://doi.org/10.3389/fimmu.2017.01626.

51. Klopp AH, Gupta A, Spaeth E, Andreeff M, Marini F 3rd. Concise review: dissecting a discrepancy in the literature: do mesenchymal stem cells support or suppress tumor growth? Stem Cells. 2011;29(1):11-9 https://doi. org/10.1002/stem.559.

52. Lee ST, Jang JH, Cheong J-W, Kim JS, Maemg HY, Hahn JS, et al. Treatment of high-risk acute myelogenous leukaemia by myeloablative chemoradiotherapy followed by co-infusion of T cell-depleted haematopoietic stem cells and culture-expanded marrow mesenchymal stem cells from a related donor with one fully mismatched human leucocyte antigen haplotype. Br J Haematol. 2002;118(4):1128-31 https://doi. org/10.1046/j.1365-2141.2002.03767.x. 
53. Wang Z, Yu H, Cao F, Liu Z, Liu Z, Feng W, et al. Donor-derived marrow mesenchymal stromal cell co-transplantation following a haploidentical hematopoietic stem cell transplantation trail to treat severe aplastic anemia in children. Ann Hematol. 2019;98(2):473-9 https://doi.org/10.1007/s00277018-3523-2.

54. Zhao L, Chen S, Yang P, Cao H, Li L. The role of mesenchymal stem cells in hematopoietic stem cell transplantation: prevention and treatment of graftversus-host disease. Stem Cell Res Ther. 2019;10(1):182 https://doi.org/10.11 86/s13287-019-1287-9.

55. Guilak F, Estes BT, Diekman BO, Moutos FT, Gimble JM. 2010 Nicolas Andry award: multipotent adult stem cells from adipose tissue for musculoskeletal tissue engineering. Clin Orthop Relat Res. 2010;468(9):2530-40 https://doi. org/10.1007/s11999-010-1410-9.

56. Moretti P, Hatlapatka T, Marten D, Lavrentieva A, Majore I, Hass R, et al Mesenchymal stromal cells derived from human umbilical cord tissues: primitive cells with potential for clinical and tissue engineering applications. Adv Biochem Eng Biotechnol. 2010;123:29-54.

57. Hass R, Kasper C, Böhm S, Jacobs R. Different populations and sources of human mesenchymal stem cells (MSC): a comparison of adult and neonatal tissue-derived MSC. Cell Commun Signal. 2011;9(1):12 https://doi.org/10.11 86/1478-811X-9-12.

58. Harman RM, Patel RS, Fan JC, Park JE, Rosenberg BR, Van de Walle GR. Single-cell RNA sequencing of equine mesenchymal stromal cells from primary donor-matched tissue sources reveals functional heterogeneity in immune modulation and cell motility. Stem Cell Res Ther. 2020;11(1):524.

59. Li H, Guo Z, Jiang X, Zhu H, Li X, Mao N. Mesenchymal stem cells alter migratory property of $\mathrm{T}$ and dendritic cells to delay the development of murine lethal acute graftversus-host disease. Stem Cells (Dayton). 2008;26: 2531-41.

60. Wang L, Zhang H, Guan L, Zhao S, Gu Z, Wei H, et al. Mesenchymal stem cells provide prophylaxis against acute graft-versus-host disease following allogeneic hematopoietic stem cell transplantation: a meta-analysis of animal models. Oncotarget. 2016;7(38):61764-74 https://doi.org/10.18632/ oncotarget.11238.

61. Vu Q, Xie K, Eckert M, Zhao W, Cramer SC. Meta-analysis of preclinical studies of mesenchymal stromal cells for ischemic stroke. Neurology. 2014 82(14):1277-86 https://doi.org/10.1212/WNL.0000000000000278.

62. Hamidian Jahromi S, Davies JE. Concise review: skeletal muscle as a delivery route for mesenchymal stromal cells. Stem Cells Transl Med. 2019;8(5):45665 https://doi.org/10.1002/sctm.18-0208.

63. Caplan H, Olson SD, Kumar A, George M, Prabhakara KS, Wenzel P, et al. Mesenchymal stromal cell therapeutic delivery: translational challenges to clinical application. Front Immunol. 2019;10:1645 https://doi.org/10.3389/ fimmu.2019.01645

64. Moll G, Ankrum JA, Kamhieh-Milz J, Bieback K, Ringdén O, Volk HD, et al, Intravascular Mesenchymal stromal/stem cell therapy product diversification: time for new clinical guidelines. Trends Mol Med. 2019;25(2):149-63 https:// doi.org/10.1016/j.molmed.2018.12.006.

65. Fischer UM, Harting MT, Jimenez F, Monzon-Posadas WO, Xue H, Savitz SI, et al. Pulmonary passage is a major obstacle for intravenous stem cell delivery: the pulmonary first-pass effect. Stem Cells Dev. 2009;18(5):683-92 https://doi.org/10.1089/scd.2008.0253.

66. Cui LL, Kerkelä E, Bakreen A, Nitzsche F, Andrzejewska A, Nowakowski A, et al. The cerebral embolism evoked by intra-arterial delivery of allogeneic bone marrow mesenchymal stem cells in rats is related to cell dose and infusion velocity. Stem Cell Res Ther. 2015;6(1):11 https://doi.org/10.1186/ scrt544.

67. Ikehara S. A novel strategy for allogeneic stem cell transplantation: perfusion method plus intra-bone marrow injection of stem cells. Exp Hematol. 2003;31(12):1142-6 https://doi.org/10.1016/j.exphem.2003.08.020.

68. Goto T, Murata M, Terakura S, Nishida T, Adachi Y, Ushijima Y, et al. Phase study of cord blood transplantation with intrabone marrow injection of mesenchymal stem cells: a clinical study protocol. Medicine (Baltimore). 2018:97(17):e0449 https://doi.org/10.1097/MD.0000000000010449.

69. Thomas J, Kean PL, Caplan Al, Dennis JE. MSCs: Delivery Routes and Engraftment, Cell-Targeting Strategies, and Immune Modulation. Stem Cells Int. 2013;2013:732742.

70. Moll G, Alm JJ, Davies LC, Von Bahr L, Heldring N, Stenbeck-Funke L, et al. Do cryopreserved mesenchymal stromal cells display impaired immunomodulatory and therapeutic properties? Stem Cells. 2014;32(9): 2430-42 https://doi.org/10.1002/stem.1729.
71. Müller B, Wilcke A, Boulesteix AL, Brauer J, Passarge E, Boltze J, et al Improved prediction of complex diseases by common genetic markers: state of the art and further perspectives. Hum Genet. 2016;135(3):259-72 https://doi.org/10.1007/s00439-016-1636-z.

72. ChiCTR-OCN-15006595. Umbilical cord mesenchymal stem cells in the application of hematopoietic stem cell transplantation. Available at http:// www.chictr.org.cn/showproj.aspx?proj=11223. Accessed 10 Jun 2020.

73. ChiCTR-INR-16008399. Cotransplantation of haploidentical peripheral blood stem cells and mesenchymal stem cells for acute leukemia: a randomized, controlled clinical study. Available at http://www.chictr.org.cn/showproj.a spx?proj=14141. Accessed 10 Jun 2020

74. NCT01092026. Unrelated Umbilical Cord Blood Transplantation With Coinfusion of Mesenchymal Stem Cells. Available at https://clinicaltrials.gov/ ct2/show/NCT01092026? term=NCT01092026\&draw=2\&rank=1. Accessed 10 Jun 2020.

75. NCT00081055. OTI-010 for Graft-Versus-Host Disease Prophylaxis in Treating Patients Who Are Undergoing Donor Peripheral Stem Cell Transplantation for Hematologic Malignancies. Available at https:/clinicaltrials.gov/ct2/ show $/$ NCT00081055?term $=$ NCT00081055\&draw $=2 \&$ rank=1. Accessed 10 Jun 2020

76. Huedo-Medina TB, Sánchez-Meca J, Marín-Martínez F, Botella J. Assessing heterogeneity in meta-analysis: Q statistic or $P^{2}$ index? Psychol Methods. 2006;11(2):193-206 https://doi.org/10.1037/1082-989X.11.2.193.

77. Ioannidis JP, Patsopoulos NA, Evangelou E. Uncertainty in heterogeneity estimates in meta-analyses. BMJ. 2007;335(7626):914-6 https://doi.org/10.113 6/bmj.39343.408449.80.

\section{Publisher's Note}

Springer Nature remains neutral with regard to jurisdictional claims in published maps and institutional affiliations.

Ready to submit your research? Choose BMC and benefit from:

- fast, convenient online submission

- thorough peer review by experienced researchers in your field

- rapid publication on acceptance

- support for research data, including large and complex data types

- gold Open Access which fosters wider collaboration and increased citations

- maximum visibility for your research: over $100 \mathrm{M}$ website views per year

At $\mathrm{BMC}$, research is always in progress.

Learn more biomedcentral.com/submission 